Portland State University

PDXScholar

$12-14-1973$

\title{
A Study of the Adsorption of Some Atmospheric Gases on Soils of the Willamette Valley River Basin
}

Thomas R. Quale

Portland State University

Follow this and additional works at: https://pdxscholar.library.pdx.edu/open_access_etds

Part of the Chemistry Commons

Let us know how access to this document benefits you.

\section{Recommended Citation}

Quale, Thomas R., "A Study of the Adsorption of Some Atmospheric Gases on Soils of the Willamette Valley River Basin" (1973). Dissertations and Theses. Paper 1998.

https://doi.org/10.15760/etd.1997

This Thesis is brought to you for free and open access. It has been accepted for inclusion in Dissertations and Theses by an authorized administrator of PDXScholar. Please contact us if we can make this document more accessible: pdxscholar@pdx.edu. 
AN ABSTRACT OF THE THESIS OF Thomas R. Quale for the Master of Arts in Chemistry presented December 14, 1973.

Title: A Study of the Adsorption of Some Atmospheric Gases on Soils of the Willamette Valley River Basin.

APPROVED BY MEMBERS OF THE THESIS COMMITTEE:

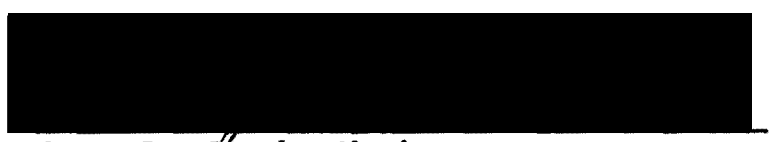

Gary L. dard, Chairman

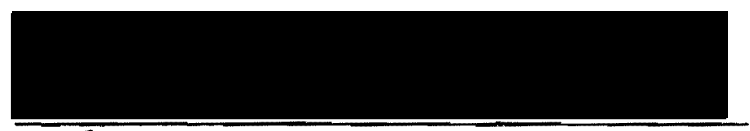

Pau1 H. Emmett

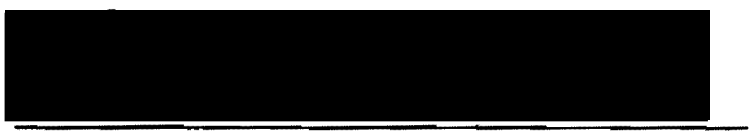

David W. Mcclure

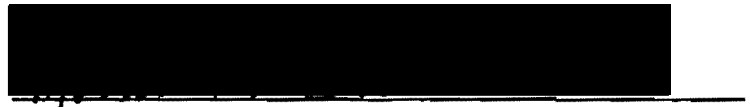

Motris B. Silverman

Recent work indicates that microorganisms present in soils can remove carbon monoxide from the atmosphere and as such constitutes a major sink. B.E.T. adsorption studies were carried out on representative soils from the Willamette Valley River Basin in order to determine their adsorptive characteristics for carbon monoxide and other gases. Attempts were made to isolate, through a non-soildestructive sterilization, the adsorptive characteristics of the soil microorganisms as well as of the test soil. 
The carbon monoxide studies show physical adsorption equivalent to the coverage of a few per cent of the surface area at $25.0^{\circ}$ and $76 \mathrm{~cm}-\mathrm{Hg}$. Adsorption studies also shows that the soil rather then the microorganisms adsorbs most of the carbon monoxide. On sterilized soil, chemical sorption of oxygen was present and was probably caused by the oxidation of dead or damaged soil microorganisms.

Hysteresis effects were present in all adsorption studies at $25.0^{\circ}$ and appears to be a characteristic of the constituents of the soil and represents a new and as yet unexplained phenomenon. 
A STUDY OF THE ADSORPTION OF SOME ATMOSPHERIC GASES ON SOILS OF THE WILIAMETTE VALLEY RIVER BASIN

by

THOMAS R. QUALE

A thesis submitted in partial fulfillment of the requirements for the degree of

\author{
MASTER OF ARTS \\ in \\ CHEMISTRY
}

\author{
Portland State University \\ 1973
}


TO THE OFFICE OF GRADUATE STUDIES AND RESEARCH:

The members of the Committee approve the thesis of Thomas R. Quale presented December 14, 1973.

Gary L. Gard, Chairman

Paul H. Emmett

David W. McClure

Morris B. Silverman

APPROVED :

Gary L! Gard, Department of Chemistry

David T. Clark, Dean of Graduate Studies and Research

February $\quad 20,1974$ 


\section{ACKNOWLEDGEMENT}

The author is pleased to take this opportunity to formally express his thanks for the generous support, encouragement, assistance, and criticism of Dr. Paul H. Emmett and Dr. Gary L. Gard.

The author would also like to express his appreciation to the following individuals for their technical assistance:

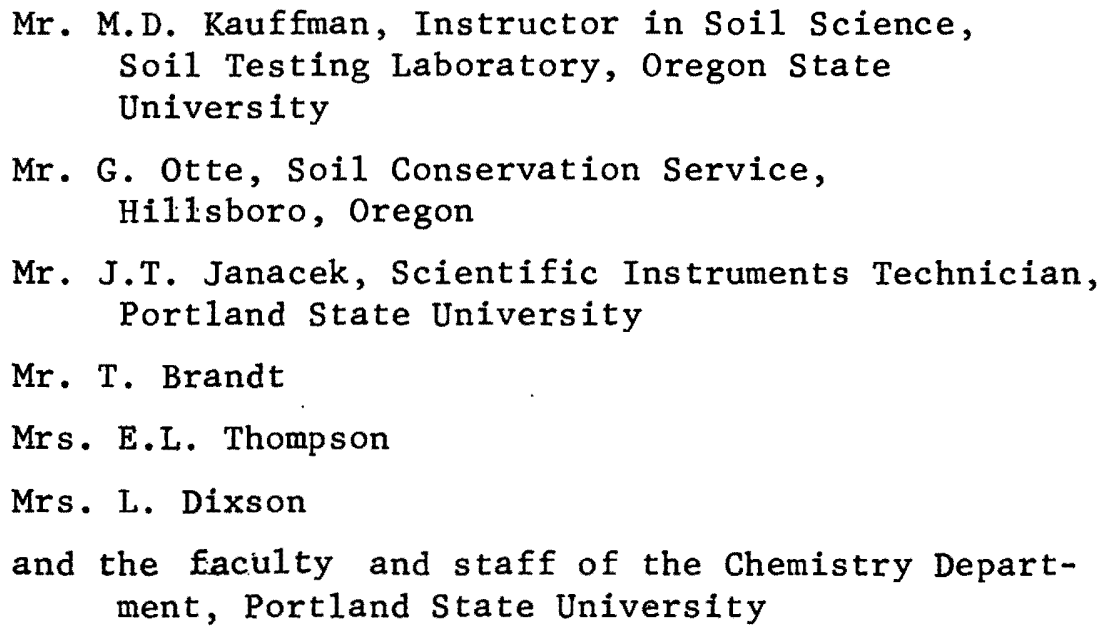

The author would also like to express his appreciation to the people of the State of Oregon; without their financial assistance none of this would have been possible.

This thesis is dedicated to my parents. 
TABLE OF CONTENTS

PAGE

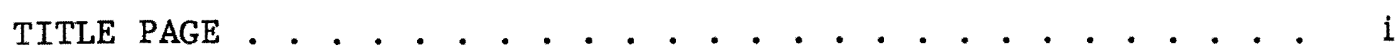

APPROVAL PAGE. . . . . . . . . . . . . . . . . . . il

ACKNOWLEDGEMENTS . . . . . . . . . . . . . . . . Iii

TABLE OF CONTENTS. . . . . . . . . . . . . . . . . IV

LIST OF TABLES. . . . . . . . . . . . . . . . . . . . V v

LIST OF FIGURES. . . . . . . . . . . . . . . . . . . . . vi

CHAPTER

I INTRODUCTION . . . . . . . . . . . . . . . . 1

II EXPERIMENTAL. . . . . . . . . . . . . . 5

Apparatus................. . 5

Experimental Procedure . . . . . . . . . 5

Materials. . . . . . . . . . . 12

III RESULTS AND DISCUSSION. . . . . . . . . . . 17

Surface Area of Soils . . . . . . . . . 17

Adsorption Studies on Nonsterilized Soils. . . . 20

- Adsorption Studies on Sterilized Soils . . . . 23

Hysteresis studies . . . . . . . . . 33

Further Hysteresis Studies . . . . . . . 41

V SUMMARY. . . . . . . . . . . . . . . . . . 46

BIBLIOGRAPHY . . . . . . . . . . . . . . . . 48 
LIST OF TABLES

TABLE

PAGE

I Organic Matter in the Willakenzie Test Soil. . . . 15

II Chemical Data on Samples of Representative Solls . . 16

III Surface Areas of Soils . . . . . . . . . . . 19

IV Adsorption of Carbon Monoxide, Nitrogen, and Oxygen on Willakenzie, Jory, and Dayton Soil Samples.............. . . 27

$\checkmark$ Surface Areas for Sterilized and Nonsterilized Willakenzie Soil . . . . . . . . 29

VI Adsorption of Carbon Monoxide and Nitrogen on Sterilized Willakenzie Soil . . . . . . . 


\section{LIST OF FIGURES}

1 Sample Bulbs... . . . . . . . . . . . 6

2 Diagram of B.E.T. Apparatus. . . . . . . . . 7

3 Surface Area Measurements of the Test Soils. . . . . 18

4 Carbon Monoxide and Nitrogen Adsorption at $25.0^{\circ}$ on a 50 Gram Sample of Nonsterilized and Nonstirred Willakenzie Soil. . . . . . . 21

5 Carbon Monoxide, Nitrogen, and Oxygen Adsorption at $25.0^{\circ}$ on a 30 Gram Sample of Nonsterilized and Stirred Willakenzie Soil. . . . . . . . . . 24

6 Carbon Monoxide, Nitrogen, and Oxygen Adsorption at $25.0^{\circ}$ on a $30 \mathrm{Gram}$ Sample of Nonsterilized and Stirred Dayton Soil . . . . . . . . . 25

7 Carbon Monoxide and Nitrogen Adsorption at $25.0^{\circ}$ on a 30 Gram Sample of Nonsterilized and Stirred Jory Soil . . . . . . . . . . 26

8 Carbon Monoxide Adsorption at $25.0^{\circ}$ on a 28 Gram Sample of Sterilized and Stirred Willakenzie Soil. . . . . . . . . . . . . . 30

9 Nitrogen Adsorption at $25.0^{\circ}$ on the 28 Gram Sample of Sterilized and Stirred Willakenzie Soil. . . 31

10 Oxygen Adsorption at $25.0^{\circ}$ on the 28 Gram Sample of Sterilized and Stirred Willakenzie Soil. . . . 34

11. Rate of Adsorption at $25.0^{\circ}$ for the 70 Hours of Oxygen Exposure on the 28 Gram Sample of Sterilized and Stirred Willakenzie Soil B.E.T. Adsorption Isotherm for Ammonia . . . . 35

12 B.E.T. Adsorption Isotherm for Ammonia at $25.0^{\circ}$ on the 28 Gram Sample of Oxygen Exposed Sterilized and Stirred Willakenzie Soil . . . . 38

13 B.E.T. Adsorption Isotherm for Ammonia at $25.0^{\circ}$ on a 1 Gram Sample of Sterilized and Nonstirred Willakenzie Soil that had not been Exposed to Oxygen . . . . . . . . . . . . . . . . 39 
14 Rate of Adsorption at $25.0^{\circ}$ on the 64 Hours of Ammonia Exposure on the 28 Gram Sample of Oxygen Exposed Sterilized and Stirred Willakenzie Soil . . . . . . . . . . . 40

15 Argon Adsorption at $25.0^{\circ}$ on the 28 Gram Sample of Oxygen and Ammonia Exposed Sterilized and Stirred Willakenzie Soil . . . . . . . . . 42

16 Nitrogen Adsorption at $25.0^{\circ}$ on a 1 Gram Sample of Silica Gel in a 6 cc Sample Bulb. . . . . . . 44

17 Argon Adsorption at $25.0^{\circ}$ on a 3 Gram Sample of Silica Gel in a 95 cc Sample Bulb. . . . . . 45 
CHAPTER I

\section{INTRODUCTION}

Carbon monoxide (CO) is a colorless, odorless gas with wellknown poisonous properties. It has a melting point of $-207^{\circ} \mathrm{C}$ and a boiling point at $-192^{\circ} \mathrm{C}$. The gas is only slightly soluble in water: $0.00440 \%$ of $0^{\circ} \mathrm{C}$ and $0.00279 \%$ at $20^{\circ} \mathrm{C}$, by weight (1).

There are certain salt solutions in which the carbon monoxide dissolves with reaction. The absorption and reaction of carbon monoxide with hemoglobin is physiologically important; among inorganic salts the univalent copper salts are important. Cuprous chloride ( $\mathrm{CuCl}$ ) solution is used in gas analysis to absorb carbon monoxide (forms $\mathrm{CuCl} \cdot \mathrm{CO} \cdot 2 \mathrm{H}_{2} \mathrm{O}$ complex) (1). For a long time only a few additional compounds of carbon monoxide were known, but now compounds of some 20 or more metallic elements are known [i.e. $\mathrm{Ni}(\mathrm{CO})_{4}, \mathrm{Fe}(\mathrm{CO})_{5}$, $\mathrm{Fe}_{2}(\mathrm{CO})_{9}, \mathrm{Cr}(\mathrm{CO})_{6}, \mathrm{KCO}$, etc.] (1).

While a great deal is known about carbon monoxide in the laboratory, we are at a loss to explain its fate in the environment. Carbon monoxide is the second most abundant pollutant in urban air; it is exceeded only by carbon dioxide and generally exceeds all other pollutants combined.

The various major environmental sources of carbon monoxide are derived from:

1. Incomplete combustion of fossil fuels.

2. Coal, volcanic, marsh, and natural gases. 
3. Marine hydrozoan jellyfish (siphonophores).

4. Methane oxidation by $\mathrm{OH}$ Radicals in the troposphere.

other sources are lightning storms; seed germination; injured, cut or dried green vegetation; bladders of a number of species of brown marine algae; and photodissociation of carbon dioxide in the upper a tmosphere.

Ambient concentrations of carbon monoxide in the earth's atmosphere has been estimated to vary between 0.04 to 0.90 parts per million (2). To this ambient concentration, the world's production of carbon monoxide is globally adding over two hundred million metric tons annually $(2,3)$. Using this conservative production estimate, the ambient concentration of carbon monoxide would be expected to double every four or five years. However, due to its relatively short residence time in the atmosphere (approximately 0.1 years) (4) the ambient concentration of carbon monoxide is surprisingly constant.

This unexpected result strongly suggests that there are sinks operating in nature to produce this effect. Three major sinks are:

1. Chemical reactions of carbon monoxide in the atmosphere

2. Plant activity

- 3. Soil microorganisms activity

of particular interest is the ability of certain microorganisms (Bacillus oligocarbophilus and Methano-sarcina barkerii) to convert carbon monoxide into carbon dioxide or methane (5). Recent work reported by Inman (6) demonstrates that soil can remove carbon monoxide from 
the atmosphere and as such constitutes a major sink. Inman further demonstrated that the "soil's ability to remove carbon monoxide from the atmosphere is ascribed to the activity of soil microorganisms".

A major question, unanswered by Inman's work, deals with the method by which the amounts of carbon monoxide in the atmosphere are concentrated in the soil such that its conversion, by soil microorganisms, wil1 represent a major sink. Therefore, a major purpose of this research is to determine the adsorptive capacity (via physical or chemical means) of various soils.

If strong adsorptive forces are operative a mechanism could be established by which large amounts of atmospheric carbon monoxide are concentrated in the soil thereby being made accessible to microorganisms.

In order to determine the magnitude of this effect, the adsorptive characteristics of various test soils in the Willamette Valley River Basin were measured. Furthermore, experiments were carried out in order to determine whether the adsorption of carbon monoxide by various test soils was physical or chemical in nature. [Attempts were made to isolate, through a non-soil-destructive sterilization, the adsorptive characteristics of the microorganisms as well as of the test soil.] It is of interest to point out that the absorptive properties of dried azotobacter have been measured (7). However, no literature has been found on the adsorption studies of carbon monoxide on soils or its microorganimsm prior to this work.

The adsorptive characteristics of the test soils were determined by the method established by Brunauer, Emmett, and Teller (8). The 
work up of all data was carried out using their standardized methods. In addition to the carbon monoxide studies, preliminary results obtained with nitrogen, oxygen, ammonia, and argon on the test soils will be discussed.

A good estimate of the precision of the apparatus can be seen from the reproducibility of points in the nitrogen and argon runs on silica gel. The largest deviation between the adsorption and desorption points shown is $0.004 \mathrm{cc} / \mathrm{sample}$ and $0.04 \mathrm{cc} / \mathrm{sample}$ in Figures 16 and 17 , respectively.

A11 temperatures recorded in this work are in degrees centigrade. 
CHAPTER II

EXPER IMENTAL

\section{APPARATUS}

The adsorption apparatus used throughout this work is shown in Figures 1 and 2 , and consists of the following $(9,10)$ :

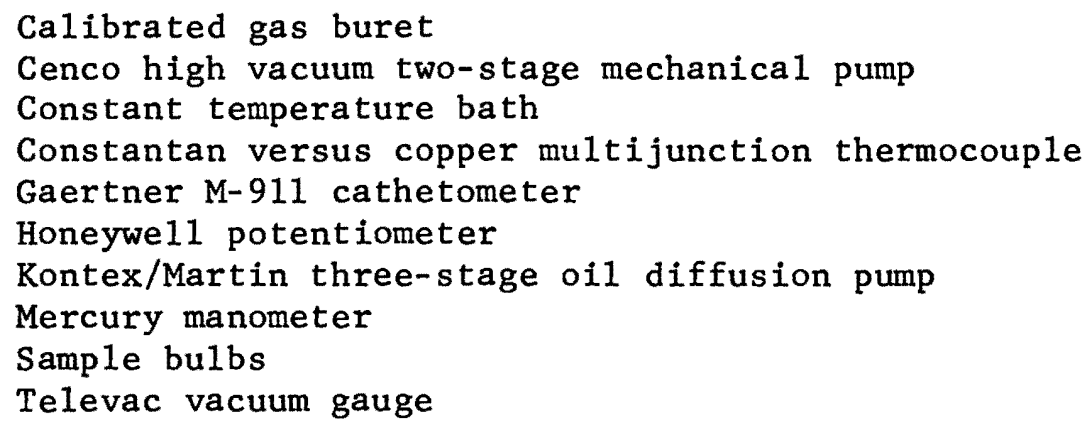

\section{EXPERIMENTAL PROCEDURE}

The method of operation is not complicated and will be discussed in detail (10). The sample bulb (see Figure 1) containing a sufficient amount of soil or standard (Copper or Silica Gel) is connected to the apparatus below stopcock (T). The sample bulb is then evacuated to one micron pressure. If the sample bulb contained a new soil, evacuation would continue for a period of not less than three days at room temperature to insure the removal of liquid water, water vapor, and other physically adsorbed gases. If the sample bulb contained a sample that has been previously exposed to a test gas (i.e., carbon monoxide, nitrogen, helium, oxygen, or argon), evacuation would continue for a period of not less than eight hours. 


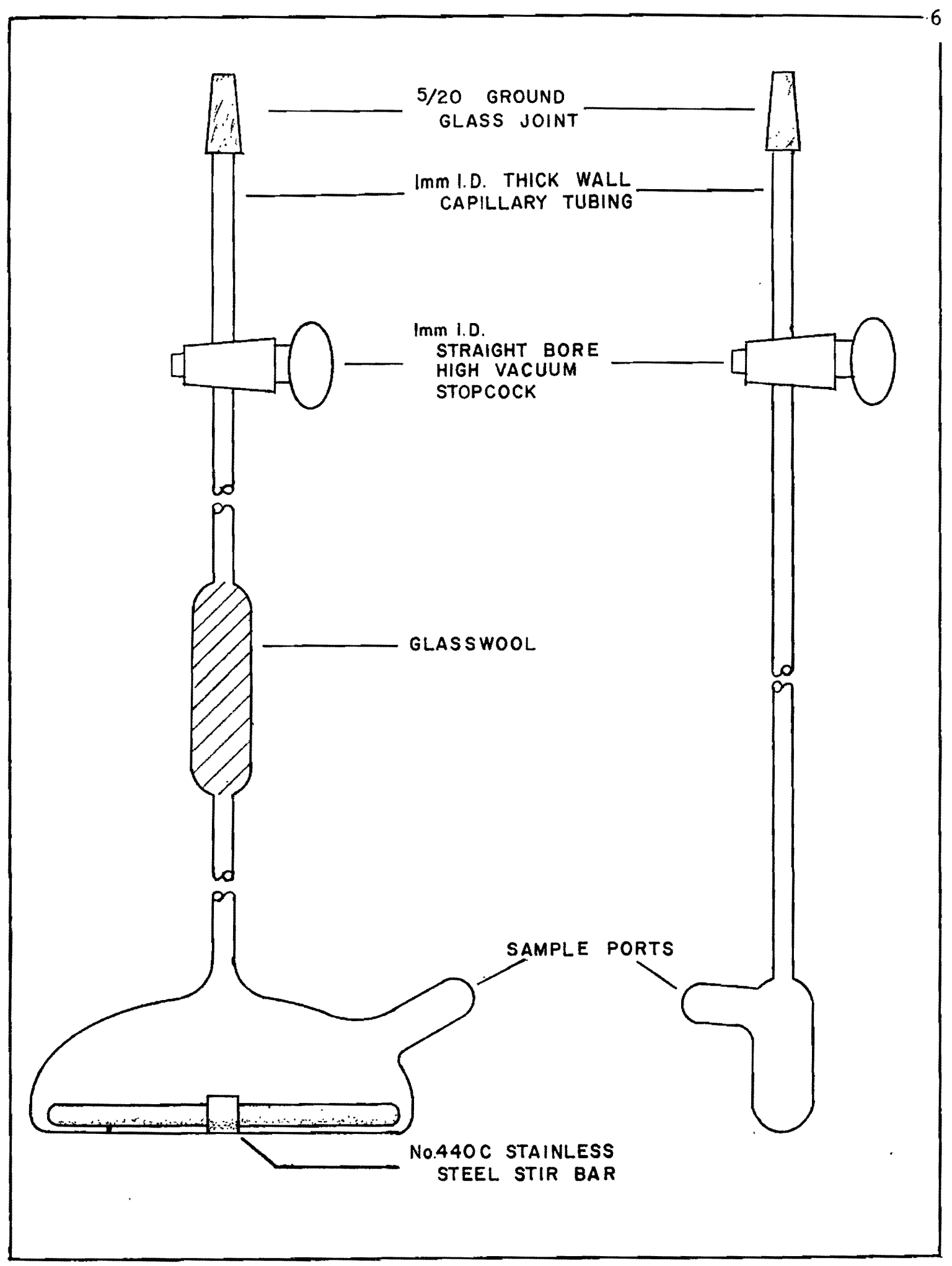

F1gure 1. Sample bulbs. 


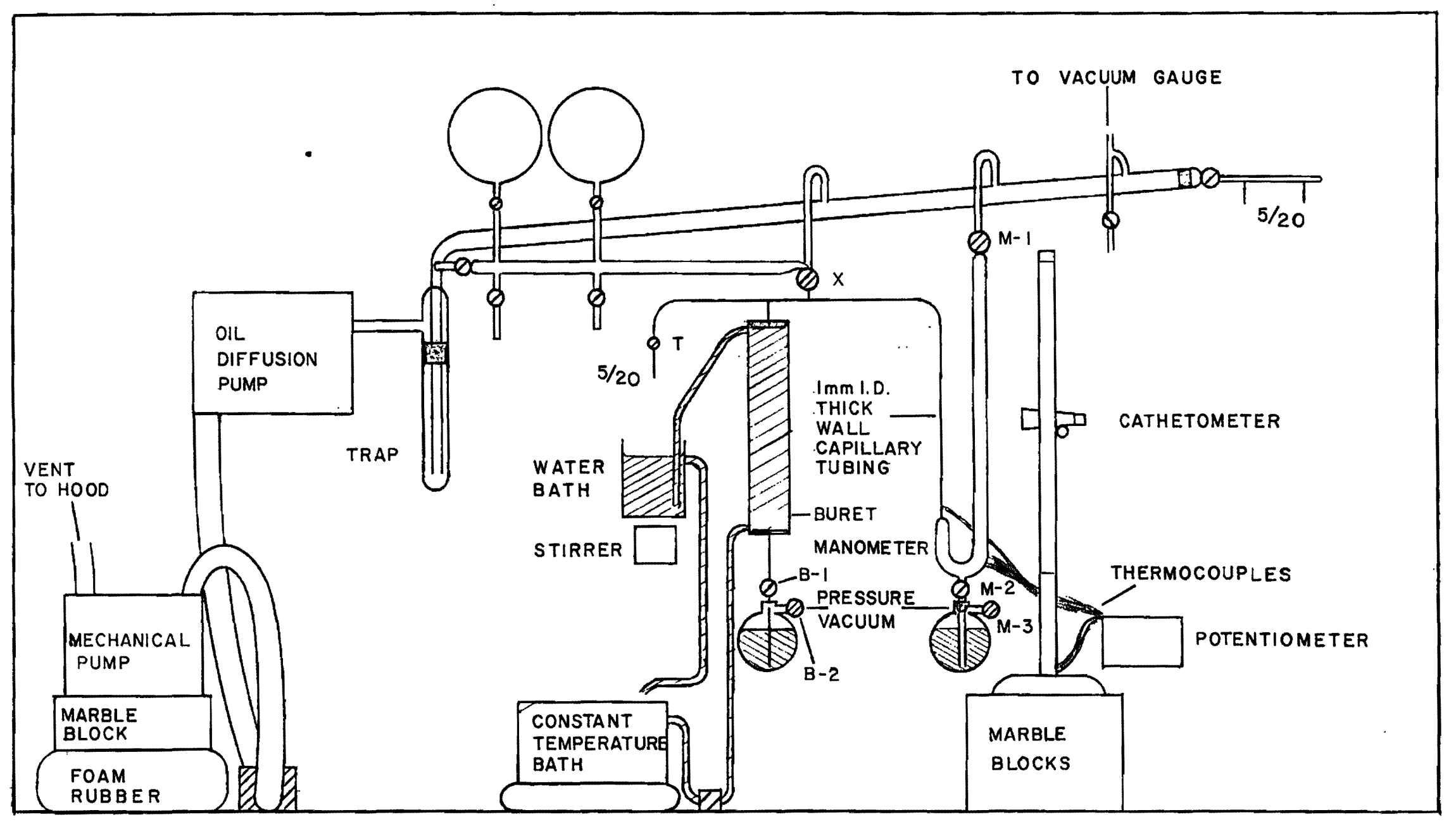

Figure 2. Diagram of B.E.T. apparatus. 
The volume of gas admitted to the B.E.T. system is then determined by the following procedure. The entire system is evacuated to one micron at room temperature for the appropriate length of time. Stopcock (T) is then closed (see Figure 2) and the helium is admitted through the three-way stopcock (X) into the buret up to a pressure not greater than that exceeding the capacity of the manometer (about $80 \mathrm{~cm}-\mathrm{Hg})$. The level of mercury in the buret is adjusted to the appropriate calibrated mark by the use of stopcocks $(B-1)$ and $(B-2)$. The telescope on the cathetometer is set at $20.000 \mathrm{~cm}$. The level of mercury in the reference leg of the manometer can be accurately set on the telescope's cross hair by careful manipulation of stopcocks $(M-2)$ and $(M-3)$. Stopcock $(M-1)$ is open to the vacuum pumps during any run to insure a vacuum over the column of mercury that is not greater than five microns. The mercury in the buret or in the manometer is always moved in the same direction, from lower to higher pressure, so that the shape of its meniscus remains as uniform as possible, thereby insuring a consistent volume in the capillary tubing between the reference mark in the reference leg of the manometer and the stopcocks $(\mathrm{T})$ and $(\mathrm{X})$. The pressure can now be recorded by setting the cross hairs on the mercury in the column leg and reading the scale on the beam of the cathetometer. The temperature of the scribed bar on the cathetometer, the mercury in the manometer, the pyrex glass tubing, and the sample bulb's water bath are a11 recorded by the use of a calibrated constantan versus copper multijunction thermocouple in reference with a crushed ice and distilled water bath in concert with a Honeywe11 potentiometer (11). 
With stopcocks (X) and (T) closed, the level of mercury in the buret can be lowered to a different calibration mark and the pressure in the enclosed system can be read as previously discussed. Continuing on to lower mercury levels in the buret and their corresponding pressures, it is possible with slight modifications (i.e. changes in expansion of the mercury, glassware, and cathetometer due to changing temperatures in the room) to determine accurately the volume of gas at standard temperature and pressure contained in the closed system as given in equation (1).

$$
\begin{aligned}
& v_{t}=\left(V_{b} T_{o} P_{i} / T_{b} P_{o}+V_{1} T_{o} P_{i} / T_{0}\right) \\
& v_{t}=\text { total volume of gas admitted to the system at STP } \\
& \mathrm{v}_{\mathrm{b}_{i}}=\text { volume in the buret at each calibration mark } \\
& v_{1}=\text { average volume in the capillary tubing from the } \\
& \text { manometer reference mark to stopcocks (T) and (X) } \\
& \text { to the highest calibration mark in the buret } \\
& P_{i}=\text { pressure corrected for the thermal expansion of } \\
& \text { mercury in the closed system for each corresponding } \\
& \text { calibration mark } \\
& \mathrm{T}=\text { temperature of the capillary tubing } \\
& T_{b}=\text { temperature of the gas buret } \\
& \mathrm{T}_{0}, \mathrm{P}_{0}=\text { standard temperature and pressure }
\end{aligned}
$$

The correction for the nonideality of all gases used at $25.0^{\circ}$ is not significant except for ammonia where it must be taken into account for all volumes (10).

The volume required to fill the space not occupied by soil or the compact glass wool in the sample bulb is now determined in the adsorption and desorption mode using helium gas. With the level of 
mercury in the buret corresponding to a pressure of about 0.1 atmospheres, the stopcock $(T)$ is opened. The system is allowed to come to equilibrium; generally 10 to 30 minutes. Then the calibrated mark of mercury in the buret, the pressure in the adjusted manometer, and the temperature is recorded. The level of mercury in the buret is then raised to the next significantly higher pressure leve1, allowed to attain equilibrium, and then recorded.

In a similar manner, this process is continued until the next higher level of mercury in the buret would exceed the maximum pressure for the manometer. This completes the adsorption run for a particular gas. The desorption run is performed in a very similar manner.

The average volume of helium required to fill the empty space to a unit pressure for the adsorption and desorption process can be calculated by using equation (2).

$$
\begin{aligned}
& \mathrm{V}_{\mathrm{He}}=\left(\mathrm{V}_{t}-\left(\mathrm{V}_{\mathrm{b}_{i}} \mathrm{~T}_{\mathrm{o}} \mathrm{P}_{i} / \mathrm{T}_{\mathrm{b}} \mathrm{P}_{\mathrm{o}}\right)-\left(\mathrm{V}_{i} \mathrm{~T}_{\mathrm{o}} \mathrm{P}_{i} / \mathrm{TP}_{\mathrm{o}}\right)\right) / \mathrm{P}_{i} \\
& \mathrm{~V}_{\mathrm{He}}= \begin{array}{l}
\text { average volume of helium to fill the empty } \\
\text { space per unit pressure }
\end{array} \\
& \mathrm{V}_{t}, \mathrm{~V}_{\mathrm{b}_{i}}, \mathrm{~T}_{\mathrm{o}}, \mathrm{P}_{\mathrm{o}} \cdot \text {. same as in equation (1) }
\end{aligned}
$$

The value of $\mathrm{V}_{\mathrm{He}}$ for the adsorption and desorption run should be the same within experimental error since helium does not adsorb but merely fills the unoccupied space in the sample bulb. The volume of a particular gas adsorbed by the soil can now be determined. The entire system is evacuated to one micron at room temperature for a period of not less than eight hours. 
With stopcock (T) closed, admission of the desired gas (nitrogen, carbon monoxide, oxygen, argon or ammonia) to the buret can be accomplished through stopcock (X). In a similar manner as described for helium the level of mercury in the buret is varied and the corresponding pressure and temperature recorded so that the average total volume of desired gas admitted to the closed system can be calculated using equation (1). The stopcock (T) is now opened to the sample bulb and the adsorption and desorption runs are then recorded in a manner previously discussed.

The volume of adsorbed gas is then calculated via equation (3):

$$
v_{a}=V_{t}-\left(V_{b_{i}} T_{0} P_{i} / T_{b} P_{o}\right)-\left(V_{1} T_{0} P_{i} / T P_{0}\right)-\left[V_{H e} P_{i}\left(1+\alpha\left(P_{i} / P_{0}\right)\right)\right]
$$

$\mathrm{V}_{\mathrm{a}}=$ volume of gas absorbed

$\alpha=$ correction factor required to take into account the imperfection of the gas at the temperature of the sample bulb bath (10) and at 1 atmospheric pressure

$\mathrm{P}_{i}, \mathrm{P}_{0}, \mathrm{~V}_{\mathrm{t}}, \mathrm{V}_{\mathrm{b}} \cdot$. . same as in equation

By plotting the volume of gas adsorbed versus pressure, one obtains curves from whose shape it is possible to determine whether physical or chemical adsorption is occurring.

In order to determine the surface areas of soils and standards, adsorption studies with nitrogen are performed at $-195.8^{\circ}$. The volume of a monolayer of nitrogen adsorbed at that temperature is calculated using equation (4): 


$$
\begin{aligned}
& \mathrm{P}_{\mathrm{i}} / \mathrm{V}_{\mathrm{a}}\left(\mathrm{P}^{\circ}-\mathrm{P}_{\mathrm{i}}\right)=1 / \mathrm{V}_{\mathrm{m}} \mathrm{C}+\left((\mathrm{C}-1) / \mathrm{V}_{\mathrm{m}} \mathrm{C}\right)\left(\mathrm{P}_{\mathrm{i}} / \mathrm{P}^{\circ}\right) \\
& \mathrm{V}_{\mathrm{m}}=\begin{array}{l}
\text { the volume of gas, usually } \mathrm{N}_{2} \text {, required to cover } \\
\text { the surface of the soil to } \mathrm{a}^{2} \text { depth of one monolayer }
\end{array} \\
& \mathrm{C}=\text { constant at a given temperature } \\
& \mathrm{P}^{\circ}=\begin{array}{l}
\text { the vapor pressure of the gas at the temperature } \\
\text { of the sample bulb bath }
\end{array}
\end{aligned}
$$

Plotting $P_{i} / V_{a}\left(P^{\circ}-P_{i}\right)$ versus $P_{i} / P^{\circ}$ should give a straight line with a slope of $(\mathrm{C}-1) / \mathrm{V}_{\mathrm{m}} \mathrm{C}$ and an intercept of $1 / \mathrm{V}_{\mathrm{m}} \mathrm{C}$. From the volume of a monolayer, the average surface area of the soil can be calculated (10).

\section{MATERIALS}

Helium, nitrogen, and argon gases were obtained from Airco, chemically pure. The gases were passed through a drying tube containing Drierite for removing any water vapor. The oxygen gas used was obtained also from Airco at a purity of U.S.P. The research grade carbon monoxide was obtained from Matheson Gas Products with a 1ist of impurities as follows:

$\begin{array}{lr}\text { Hydrogen } & \text { less than } \\ \text { Oxygen } & 10 \mathrm{ppm} \\ \text { Argon } & 20 \mathrm{ppm} \\ \text { Nitrogen } & 20 \mathrm{ppm} \\ \text { Carbon dioxide } & 100 \mathrm{ppm} \\ \text { Methane } & 10 \mathrm{ppm} \\ & 2 \mathrm{ppm}\end{array}$

This gas was passed through a trap cooled to $-78^{\circ}$ and then through a drying tube containing sodium hydroxide pellets and anhydrous calcium chloride to insure removal of carbon dioxide and water vapor.

* This is the standard equation used for calculating surface areas. For derivation see reference (8). 
respectively. Anhydrous ammonia gas was obtained from the Matheson Company Inc., with a designated purity of $99.99 \%$.

Copper and silica gel were used in order to standardize procedures and compare results with other published data. The Copper, Purified, Powder, CX 1925 CB 963 obtained from Matheson Coleman and Bel1, with a purity for other metals of $99.95 \%$ was oven dried in air at $100^{\circ}$ for 24 hours. Silical Gel 6-12 mesh, sX 144 CB 963 was obtained from Matheson Coleman and Bell, with no indication of purity 1isted. This standard was treated to the same procedure as that for the sterilization of soils, in order to check the reproducibility of the apparatus .

The soils used in this work were obtained from the Soil Testing Laboratory, Oregon State University, Corval1is, Oregon, 97331. The soil was collected in the desired area from the first seven inches of surface soil. The samples were air dried at room temperature, mechanically pulverized in a mortar and rotating pestle then passed through a 1.0 to $1.5 \mathrm{~mm}$ sieve (12). A sufficient amount of soil was transferred into sample bulbs, sealed, weighed and evacuated to one micron for a period of not less than three days.

The soils chosen were the Benchmark series soils which occur most frequently in the Willamette Valley River Basin. A brief description of each series soils used in this work will be given next (13). However, a more complete description of the soils can be obtained from the Soil Testing Laboratory, Oregon State University or the Soil Conservation Service, U.S. Department of Agriculture, P. O. Box 497, Hi11sboro, Oregon, $97123(14,15)$. 
The Amity series consists of very deep, somewhat poorly drained soils, formed in old water-deposited silty material on nearly level or slightly convex valley floor terraces of the willamette Valley. Slopes may range up to five percent. Typically it has very dark grayish brown, friable, silt loam surface layers and grayish brown or light olive brown, firm, silty clay loam subsoil. The soil varies from medium to slightly acidic.

The Dayton series consists of very deep, poorly drained, light colored soils formed in old water-deposited materials on nearly level and somewhat concave valley floor terraces, predominantly in the southern part of the Willamette Valley. Typically it is dark gray, friable, silt loam surface layers with the rooting depth of plants restricted by the clay subsoil. The soil varies from medium to slightly acidic.

The Jory series consists of very deep, we11 drained soils formed on generally stable old upland surfaces in the low foothills of the Willamette Valley. Most areas have slopes of less than 12 percent, but slopes may range up to 30 percent. Jory soils typically have very dark, reddish brown, friable, silty clay surface layers and dark reddish brown, firm clay subsoils. The surface layers are medium acidic and the subsoils are strongly acidic.

The Willakenzie series consists of moderately deep, well drained somewhat reddish soils formed on gently sloping to steep foothills generally along the marginal areas of the Willamette Valley. Most areas have slopes less than 30 percent. Typically, these soils have dark brown, friable, silty clay loam surface layers and brown, to 
reddish brown, friable, silty clay loam subsoils that are underlain at depths greater than 30 inches by fractured sedimentary bedrock. Willakenzie soils are moderately acidic.

The Woodburn series consists of very deep, moderately well drained soils formed in old water-deposited silty material on nearly level broad terraces in the Willamette Valley. Slopes may range up to 20 percent. These soils typically have very dark brown, friable silt loam surface layers and dark brown silty clay loam subsoil, generally with a firm, slightly brittle layer. The Woodburn woils are slightly acidic.

Listed in Table $I$ is an analysis of the organic carbon, nitrogen, and hydrogen in the Willakenzie test soil. Test II lists some of the chemical data that has been previously reported in the 1iterature for these soils.

TABLE I

ORGANIC MATTER IN THE WILLAKENZIE TEST SOIL (15)

Organic Carbon

Organic Hydrogen

Organic Nitrogen

C/N Ratio
$1.46 \%$

$0.84 \%$

$0.16 \%$

$9.1 \%$ 
TABLE II

- chemical data on SAMPles of Representative soils (16).

\begin{tabular}{|c|c|c|c|c|c|c|c|c|c|c|}
\hline \multirow{2}{*}{$\begin{array}{r}\text { Series } \\
\text { Soils }\end{array}$} & \multirow{2}{*}{$\begin{array}{l}\text { Depth } \\
\text { Inch }\end{array}$} & $\mathrm{pH}$ & \multicolumn{2}{|c|}{ ORGANIC MATTER } & \multirow[b]{2}{*}{$\mathrm{C} / \mathrm{N}$} & \multicolumn{2}{|c|}{$\begin{array}{r}\text { EXTRACTABLE } \\
\text { Meq } / 100 \mathrm{~g}\end{array}$} & $\begin{array}{l}\text { CATIONS } \\
\text { soil }\end{array}$ & \multirow[b]{2}{*}{$\mathrm{Na}$} & \multirow[b]{2}{*}{$\mathrm{K}$} \\
\hline & & $\mathrm{H}_{2} \mathrm{O} \quad 1: 1$ & Carbon & Nitrogen & & $\mathrm{Ca}$ & $\mathrm{Mg}$ & $\mathrm{H}$ & & \\
\hline Amity & $0-7$ & 5.3 & $3.01 \%$ & $0.227 \%$ & 13.3 & 9.4 & 2.6 & 15.2 & 0.1 & 1.1 \\
\hline Dayton & $0-9$ & 5.1 & $1.51 \%$ & $0.128 \%$ & 12 & 3.6 & 1.7 & 9.7 & 0.2 & 0.1 \\
\hline Jory & $0-5$ & 5.4 & $3.59 \%$ & $0.232 \%$ & 15.5 & 9.8 & 2.2 & 20.9 & 0.1 & 0.9 \\
\hline Willakenzie* & $0-4$ & 6.0 & $3.44 \%$ & $0.247 \%$ & 14 & 20.2 & 3.3 & 12.9 & 0.2 & 0.7 \\
\hline Woodburn & $0-9$ & 6.5 & $1.78 \%$ & $0.127 \%$ & 14 & 7.3 & 2.6 & 8.2 & 0.5 & 0.3 \\
\hline
\end{tabular}

*The two Willakenzie soils listed in Table I and II are different samples of the same soil series. The differences in the organic matter could be due to the degree of cultivation, fertilization, and nonhomogeneity of the general soil series. 
CHAPTER III

RESULTS AND DISCUSSION

\section{Surface Area of Soils}

In order to measure the adsorptive capacity of soils, the five most frequently occurring soils in the Willamette Valley River Basin described previously in Table II were studied (these soils are Amity, Dayton, Woodburn, Jory, and Willakenzie).

Figure 3 gives the results for the nitrogen adsorption isotherm studies carried out with these five soils. As can be seen from the curves, the soils seem to fall into two groups. The first group consisting of Amity, Dayton, and Woodburn possess similar nitrogen adsorption which is probably due to their geomorphical similarities. The second group, consisting of Jory and Willakenzie, possess similar nitrogen adsorption as well as being related geomorphically.

The surface areas for the five soils are listed in Table III. The values for the surface areas fall into the same groups mentioned earlier. The largest surface areas obtained are with Jory and Willakenzie soils. These soils are from the foothills of the Willamette Valley River Basin where drainage is high. The lowest surface areas were obtained with Amity, Dayton, and Woodburn soils. These soils are from the valley floor and as such have poor drainage. 


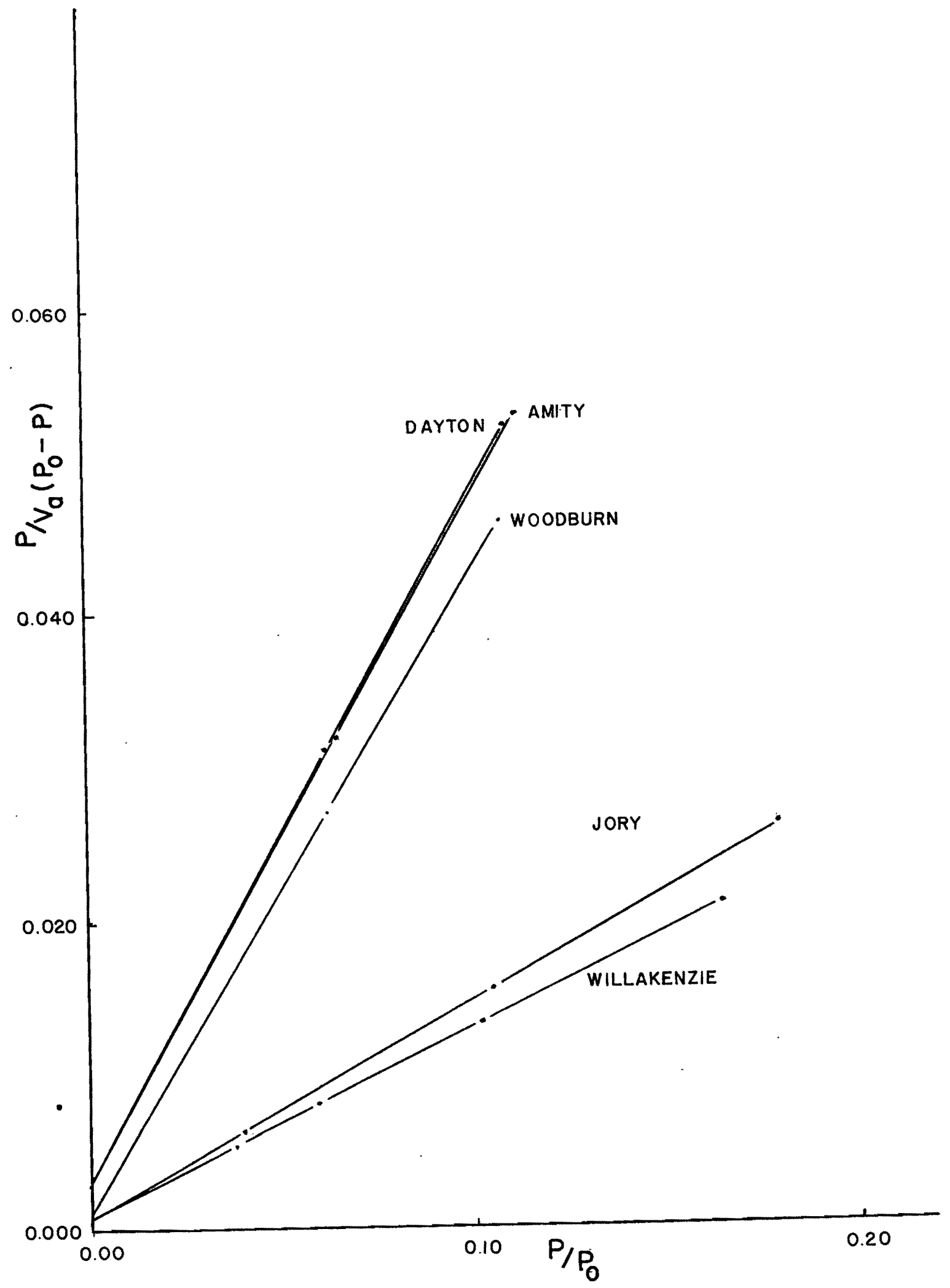

Figure 3. Surface area measurements of the test soils. 


\section{TABLE III}

\section{SURFACE AREA OF SOILS*}

\begin{tabular}{|c|c|c|c|c|}
\hline Soil & $\begin{array}{r}\text { Air Dried } \\
\text { wt. of soil } \\
(\mathrm{g}) \\
\end{array}$ & $\begin{array}{r}\mathrm{V}_{\mathrm{m}} \text { from Data } \\
\left(\mathrm{cc} \text { of } \mathrm{N}_{2}\right) \\
\operatorname{sTp} \\
\end{array}$ & $\mathrm{v}_{\mathrm{m}} / \mathrm{gram}$ & $\begin{array}{c}\text { Surface Area } \\
\left(\mathrm{m}^{2} / \mathrm{g}\right)\end{array}$ \\
\hline Amity & $1.1355 \mathrm{~g}$ & $2.18 \mathrm{cc}$ & $1.92 \mathrm{cc} / \mathrm{g}$ & $8.41 \mathrm{~m}^{2} / \mathrm{g}$ \\
\hline Dayton & $1.0495 \mathrm{~g}$ & $2.18 \mathrm{cc}$ & 2.08 & 9.11 \\
\hline Woodburn & $0.8685 \mathrm{~g}$ & $2.37 \mathrm{cc}$ & 2.73 & 12.0 \\
\hline Jory & $1.0445 \mathrm{~g}$ & $7.08 \mathrm{cc}$ & 6.78 & 29.7 \\
\hline Willakenzie & $1.0216 \mathrm{~g}$ & $7.81 \mathrm{cc}$ & 7.64 & 33.5 \\
\hline
\end{tabular}

* For a rough comparison: Previous work on Barnes and Cecil soils gave respectively $44.2 \mathrm{~m}^{2} / \mathrm{g}$ and $32.3 \mathrm{~m}^{2} / \mathrm{g}$, surface areas $(17,18)$. 


\section{Adsorption Studies on Nonsterilized Soils}

Due to the large surface area of Willakenzie, more detailed studies were carried out with nitrogen and carbon monoxide. A 50 gram sample of Willakenzie soil was tested with a variety of gases at room temperature in order to determine the adsorptive characteristics of this soil at $25.0^{\circ}$.

Figure 4 compares successive adsorption runs of helium, carbon monoxide, and nitrogen gases with the same soil at the same temperature. The sequence of events for this study was as follows:

1. Evac to 1 micron for 3 days at room temperature.

2. He 1st exposure at $25.0^{\circ} \quad \mathrm{V}_{\mathrm{He}}=1.0317 \pm 0.0001 \mathrm{ml} / \mathrm{cm} \mathrm{Hg}$

3. Evac 18 hours at room temperature.

4. Co 1st exposure at $25.0^{\circ} \quad \mathrm{V}_{\mathrm{a}}$ at $76 \mathrm{~cm} \mathrm{Hg}=5.86 \mathrm{ml} \mathrm{STP}$

5. Evac 19 hours at room temperature.

6. $\mathrm{N}_{2}$ Ist exposure at $25.0^{\circ} \quad \mathrm{V}_{\mathrm{a}}$ at $76 \mathrm{~cm} \mathrm{Hg}=3.65 \mathrm{ml} \mathrm{STP}$

7. Evac 91 hours at room temperature.

8. Co 2nd exposure at $25.0^{\circ} \quad \mathrm{V}_{\mathrm{a}}$ at $76 \mathrm{~cm} \mathrm{Hg}=7.78 \mathrm{ml} \mathrm{STP}$

9. Evac 15 hours at room temperature.

10. Co 3rd exposure at $25.0^{\circ} \quad \mathrm{V}_{\mathrm{a}}$ at $76 \mathrm{~cm} \mathrm{Hg}=8.85 \mathrm{ml}$ STP

11. Evac 18 hours at room temperature.

12. $\mathrm{N}_{2}$ 2nd exposure at $25.0^{\circ} \quad \mathrm{V}_{\mathrm{a}}$ at $76 \mathrm{~cm} \mathrm{Hg}=4.80 \mathrm{ml} \mathrm{STP}$

13. Evac 17 hours at room temperature.

14. He 2nd exposure at $25.0^{\circ} \quad \mathrm{V}_{\mathrm{He}}=1.0318 \pm 0.0001 \mathrm{ml} / \mathrm{cm} \mathrm{Hg}$

As can be seen from Figure 4 and the above sequence, there is an apparent increase in the volume of gas adsorbed between the first and second 


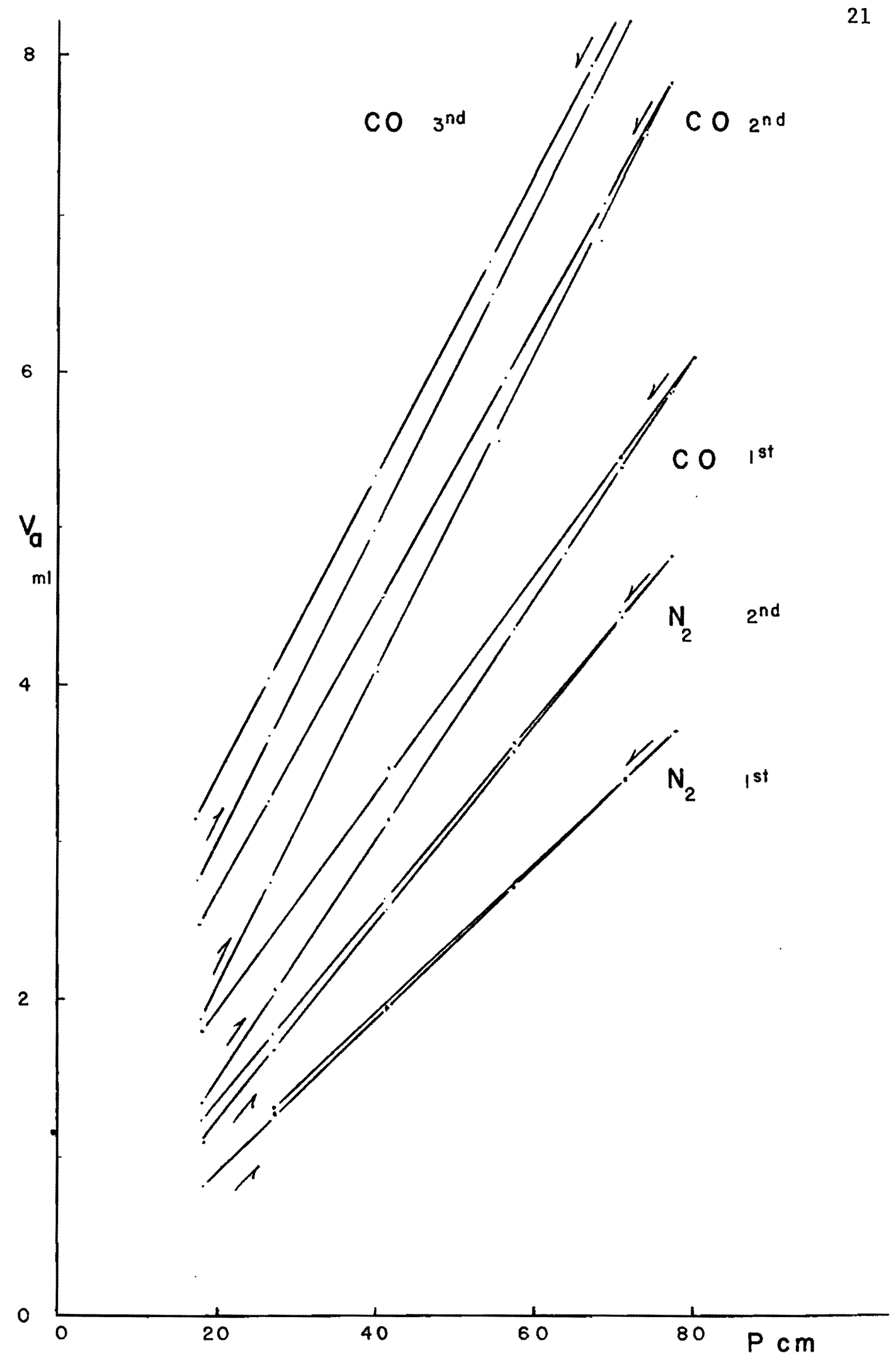

Figure 4. Carbon monoxide and nitrogen adsorption at $25.0^{\circ}$ on a 50 gram sample of nonsterilized and nonstirred Willakenzie soil. 
exposures. In the case of the nitrogen adsorption run, there is an increase in $31.5 \%$ and in the case of the carbon monoxide adsorption there is an increase of $32.8 \%$. Since the helium values at the beginning and end of this sequence of gaseous exposures did not change, the $32 \%$ increase in the volume of gas adsorbed between first and second exposures of both carbon monoxide and nitrogen and the $13.8 \%$ increase in the volume of carbon monoxide absorbed between the second and third exposures could possibly be due to a change in the accommodation coefficient which in turn could be caused by varying evacuation times. Huang (19) observed increased adsorptions on samples of Silica Alumina that had been initially evacuated at $250^{\circ}, 440^{\circ}$, and $800^{\circ}$. This would suggest that long periods of evacuation at a low temperature has the same effect as short periods at higher temperatures (18).

In addition to the increased adsorption. with repeated exposure there was found a significant difference between the adsorption and desorption process for carbon monoxide and nitrogen on Willakenzie soil. This adsorption-desorption hysteresis effect was larger for carbon monoxide than for nitrogen. It was thought that since the soil in these runs was about two centimeters deep in the sample bulb there might exist a nonuniform pressure throughout the soil resulting in retention of residual carbon monoxide or nitrogen gas in the soil.

In order to determine if the nonuniform pressure in the soil could have caused this hysteresis effect, a smaller sample of Willakenzie soil, approximately 30 grams, and a No. $440 \mathrm{c}$ stainless steel stirring bar was placed in the sample bulb. Adsorption-desorption runs were carried out with nitrogen, carbon monoxide, and oxygen and magnetically stirred 
at $3 \mathrm{rev} / \mathrm{min}$. The results of these runs (see Figure 5) showed that the hysteresis effect was not eliminated.

Adsorption-desorption runs were now carried out with Jory and Dayton soils in order to see if similar hysteresis effects were present. The results (see Figures 6 and 7 ) of the runs demonstrated that a similar hysteresis effect was present.

It is of major interest to compare the relative adsorptive behavior of carbon monoxide and nitrogen over Willakenzie, Jory, and Dayton soils (see Table IV). In all runs the volume $\left(\frac{c c}{g}\right)$ of carbon monoxide adsorbed is greater than the volume $\left(\frac{c c}{g}\right)$ of nitrogen or oxygen adsorbed. This relative behavior is in good agreement with previous adsorption studies of carbon monoxide, nitrogen, and oxygen on catalytic surfaces $(20,21)$. These results strongly suggest that the adsorptive process is largely physical in nature. The greater values found for carbon monoxide could be due to its having a small finite dipole moment which would enhance physical adsorption. However, the evidence indicates that no unusually large amount of carbon monoxide is physically adsorbed by the Willamette Valley soils tested.

\section{Adsorption Studies on Sterilized Soil}

In order to determine if the sterilization procedure affects the surface area, the same one gram sample of Willakenzie soil in Table II was used. The only difference in procedure was the inclusion of a cavity packed tightly with glass wool made in the capillary tubing below the stopcock so as to act as a barrier against external microorganisms once the sample had been sterilized. 


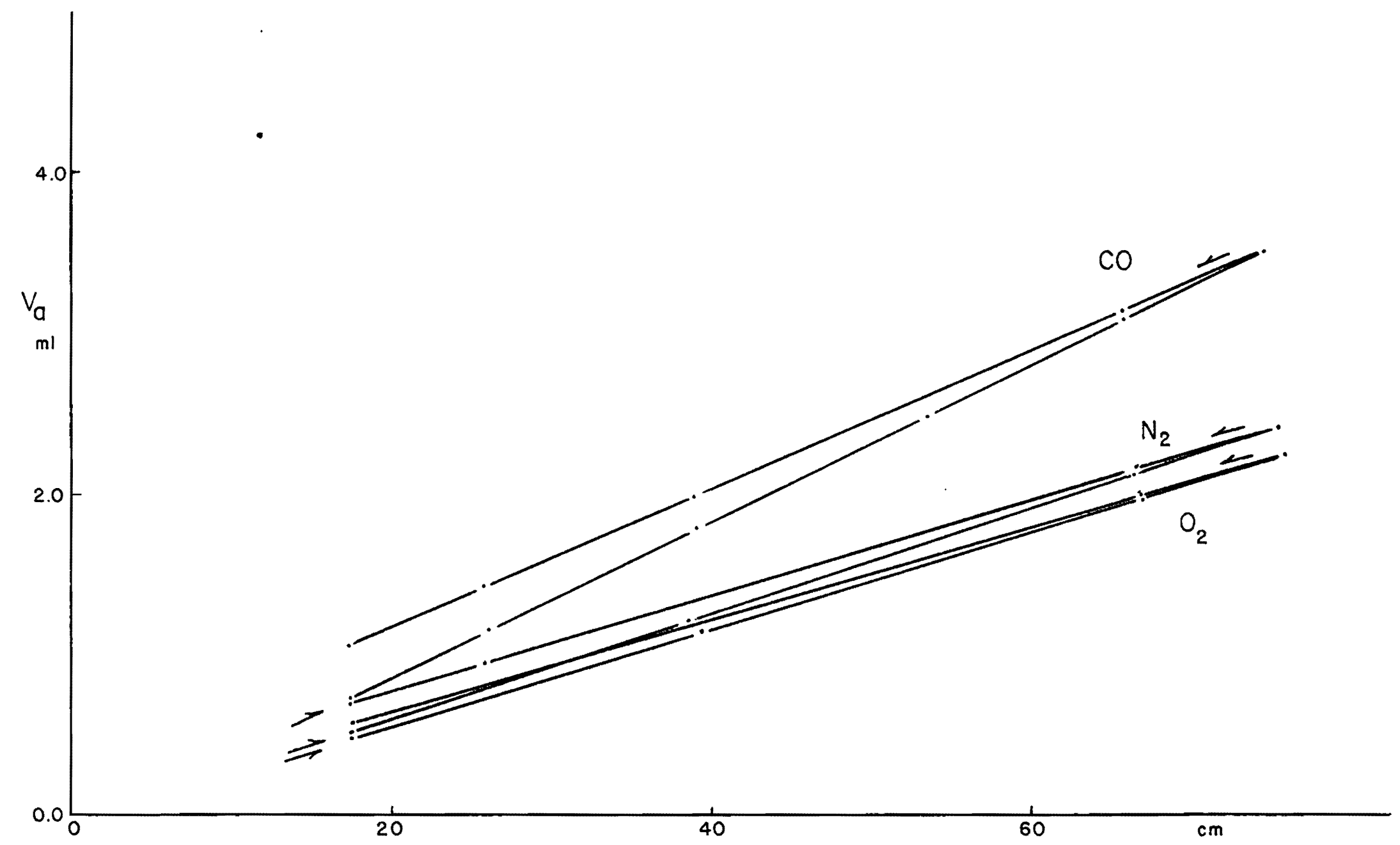

Figure 5. Carbon monoxide, nitrogen, and oxygen adsorption at $25.0^{\circ}$ on a 30 gram sample of nonsterilized and stirred Willakenzie soil. 


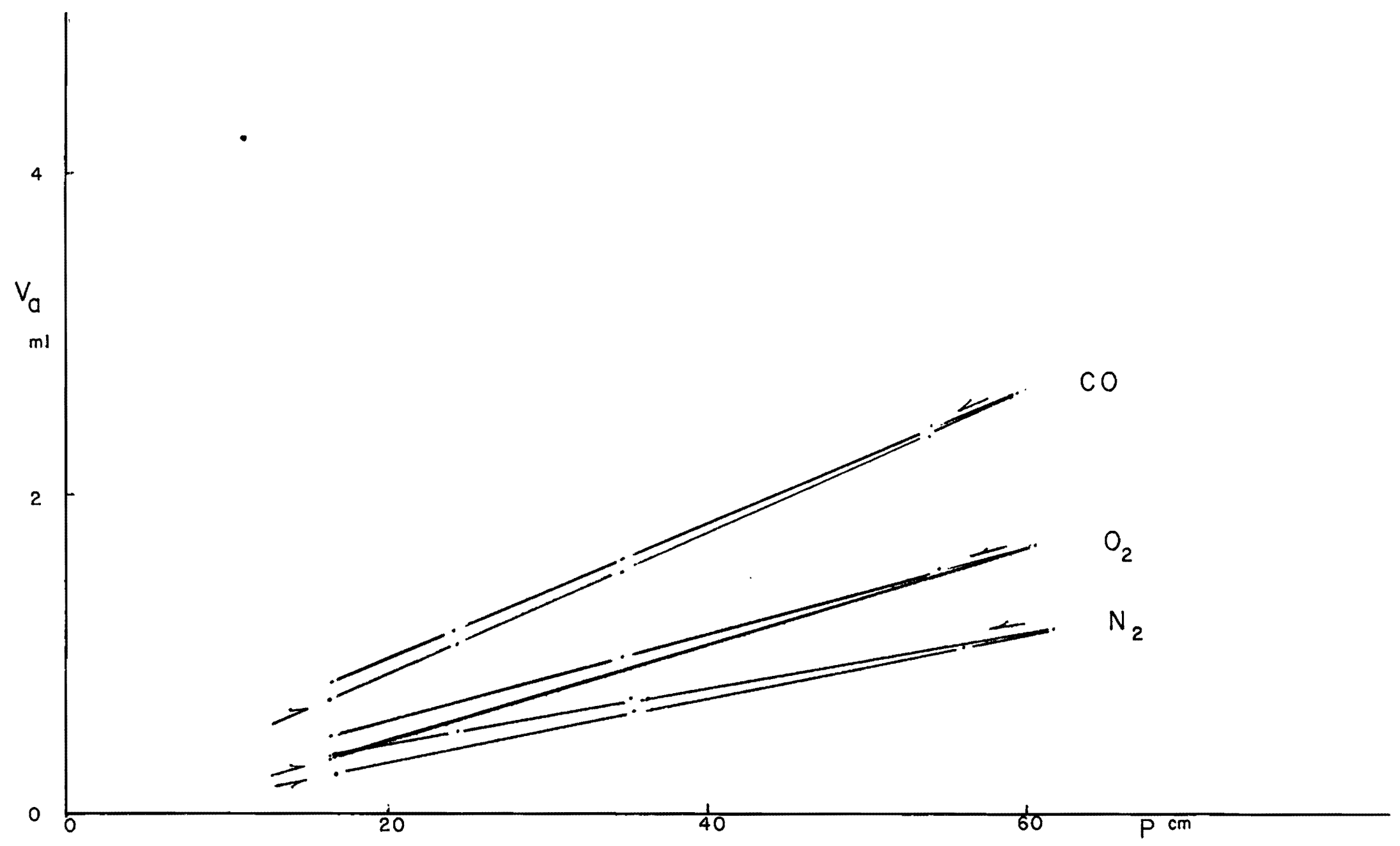

Figure 6. Carbon monoxide, nitrogen, and oxygen adsorption at $25.0^{\circ}$ on a 30 gram sample of nonsterilized and stirred Dayton soil. 


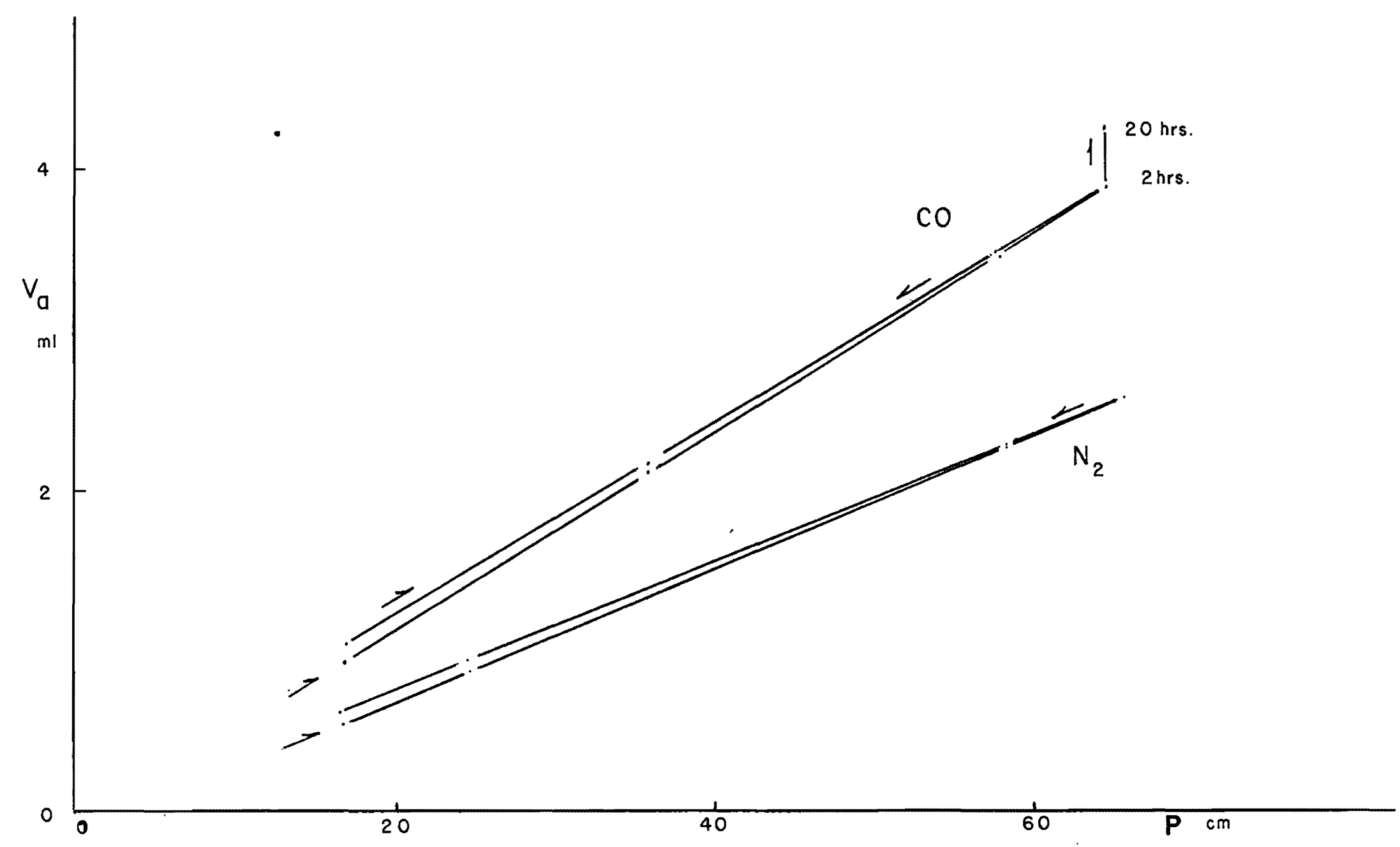

Figure 7. Carbon monoxide and nitrogen adsorption at $25.0^{\circ}$ on a 30 gram sample of nonsterilized and stirred Jory soll. 
TABLE IV

- ADSORPTION OF CARBON MONOXIDE, NITROGEN, AND OXYGEN ON WILLAKENZIE, JORY, AND DAYTON SOIL SAMPLES

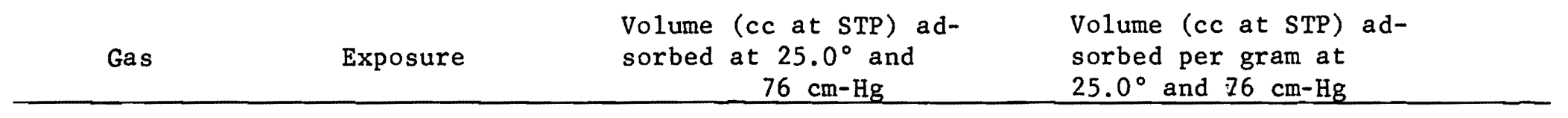

Willakenzie, Nonsterilized, Nonstirred, 50 grams

$\begin{array}{llll}\mathrm{CO} & \text { 1st } & 5.86 \mathrm{cc} & 0.119 \mathrm{cc} / \mathrm{g} \\ \mathrm{CO} & \text { 2nd } & 7.78 \mathrm{cc} & 0.158 \mathrm{cc} / \mathrm{g} \\ \mathrm{CO} & \text { 3rd } & 8.85 \mathrm{cc} & 0.180 \mathrm{cc} / \mathrm{g} \\ \mathrm{N}_{2} & 1 \mathrm{st} & 3.65 \mathrm{cc} & 0.074 \mathrm{cc} / \mathrm{g} \\ \mathrm{N}_{2} & \text { 2nd } & 4.80 \mathrm{cc} & 0.098 \mathrm{cc} / \mathrm{g}\end{array}$

Willakenzie, Nonsterilized, Stirring, 30 grams

$\begin{array}{lll}\mathrm{CO} & 1 \mathrm{st} & 3.58 \mathrm{cc} \\ \mathrm{N}_{2} & 1 \mathrm{st} & 2.41 \mathrm{cc} \\ \mathrm{O}_{2} & 1 \mathrm{st} & 2.26 \mathrm{cc}\end{array}$

$0.121 \mathrm{cc} / \mathrm{g}$

$0.082 \mathrm{cc} / \mathrm{g}$

$0.077 \mathrm{cc} / \mathrm{g}$

Jory, Nonsterilized, Stirring

\begin{tabular}{|c|c|c|c|}
\hline $\mathrm{CO}$ & 1st & $4.51 \mathrm{cc}$ & $0.151 \mathrm{cc} / \mathrm{g}$ \\
\hline $\mathrm{N}_{2}$ & $1 \mathrm{st}$ & $2.98 \mathrm{cc}$ & $0.100 \mathrm{cc} / \mathrm{g}$ \\
\hline $\mathrm{O}_{2}^{2}$ & 2nd & $3.07 \mathrm{cc}$ & $0.103 \mathrm{cc} / \mathrm{g}$ \\
\hline
\end{tabular}

Dayton, Nonsterilized, Stirring

\begin{tabular}{|c|c|c|c|}
\hline $\mathrm{CO}$ & $1 s t$ & $3.36 \mathrm{cc}$ & $0.095 \mathrm{cc} / \mathrm{g}$ \\
\hline $\mathrm{N}_{2}$ & $1 \mathrm{st}$ & $1.47 \mathrm{cc}$ & $0.040 \mathrm{cc} / \mathrm{g}$ \\
\hline $\mathrm{O}_{2}^{2}$ & 1st & $2.13 \mathrm{cc}$ & $0.060 \mathrm{cc} / \mathrm{g}$ \\
\hline
\end{tabular}


The vessel was evacuated and then filled to a pressure of $40.5 \mathrm{~cm}-\mathrm{Hg}$ with Helium gas. The vessel was placed in a preheated tube furnace so that the glass wool was not less than three centimeters inside the door of the furnace. The vesse1 remained in the furnace at a temperature of $178^{\circ}$ for not less than 20 hours (22). The vessel was then connected to the pumps and evacuated at room temperature for 48 hours before any adsorption runs were performed. While the vessel was being sterilized, the entire apparatus (manometer, manifold, buret, and capillary tubing) was also heated with a hot air gun for 2 hours while being evacuated.

The surface area of the sterilized one gram sample of Willakenzie soil

is shown in Table $\mathrm{V}$ along with the nonsterilized Willakenzie soil from Table III. As can be seen from this table, the surface areas of the sterilized and nonsterilized Willakenzie soil samples are the same within experimental error for B.E.T. measurements $(10,18)$. In order to determine the roles played by the soil and its microorganisms on the uptake of carbon monoxide, a larger sample of soil was sterilized:

28 grams of Willakenzie soil was placed in a sample bulb along with a stainless steel stirring bar and connected to the vacuum 1 ine. The capillary tubing below the stopcock was tightly packed with the glass wool. The soil was then sterilized and the volume of carbon monoxide and nitrogen gases adsorbed was measured. (See Figures 8,9 and Table VI).

In an attempt to differentiate between the magnitude of the carbon monoxide uptake by the soil and the uptake by the soil's microorganisms the following experiments were carried out: 
SURFACE AREAS FOR STERILIZED AND
NONSTERILIZED WILLAKENZIE SOIL

Series Soil

Willakenzie

Willakenzie $\underline{\text { Condition }}$

Nonsterilized

Sterilized

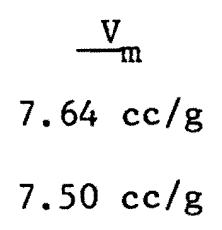

$7.50 \mathrm{cc} / \mathrm{g}$
Surface Area

$33.5 \mathrm{~m}^{2} / \mathrm{g}$

$32.9 \mathrm{~m}^{2} / \mathrm{g}$

TABLE VI

ADSORPTION OF CARBON MONOXIDE AND NITROGEN ON STERILIZED WILIAKENZIE SOIL

$\begin{array}{cc}\text { Exposure } & \text { Volume (cc at STP) } \\ & \text { adsorbed at } 25.0^{\circ} \\ & \text { and } 76 \mathrm{~cm}-\mathrm{Hg}\end{array}$

Volume (cc at STP) adsorbed per gram at $25.0^{\circ}$ and $76 \mathrm{~cm}-\mathrm{Hg}$

Willakenzie $28 \mathrm{~g}$, sterilized soil, stirring, $25.0^{\circ}$
1st exp. Co
$2.54 \mathrm{cc}$
$0.091 \mathrm{cc} / \mathrm{g}$
2nd exp. co
$2.77 \mathrm{cc}$
$0.099 \mathrm{cc} / \mathrm{g}$
1st exp. $\quad \mathrm{N}_{2}$
$2.44 \mathrm{cc}$
$0.087 \mathrm{cc} / \mathrm{g}$
2nd exp. $\quad \mathrm{N}_{2}$
$2.03 \mathrm{cc}$
$0.072 \mathrm{cc} / \mathrm{g}$ 


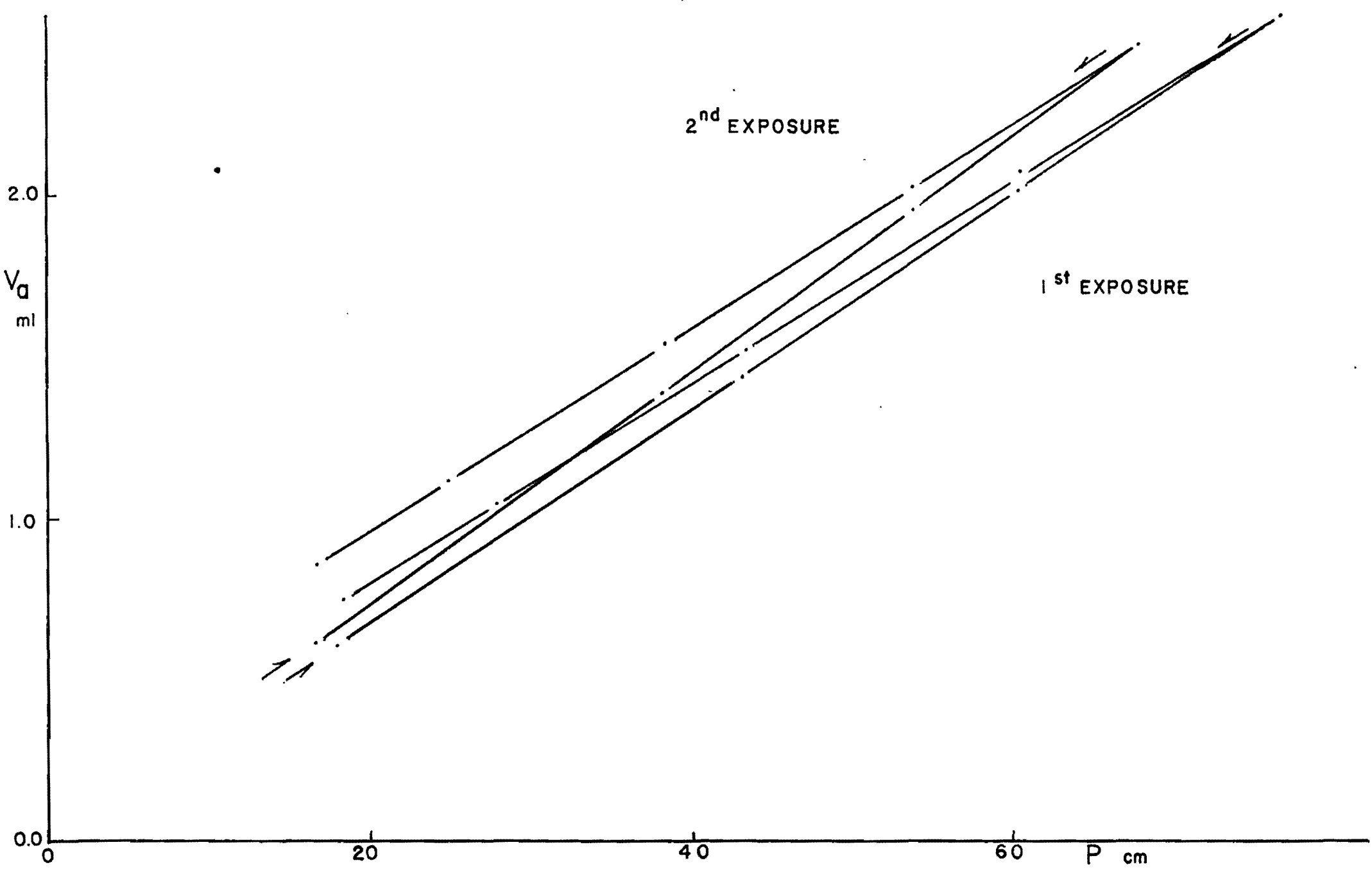

Figure 8. Carbon monoxide adsorption at $25.0^{\circ}$ on a 28 gram sample of sterilized and stirred Willakenzié soil. 


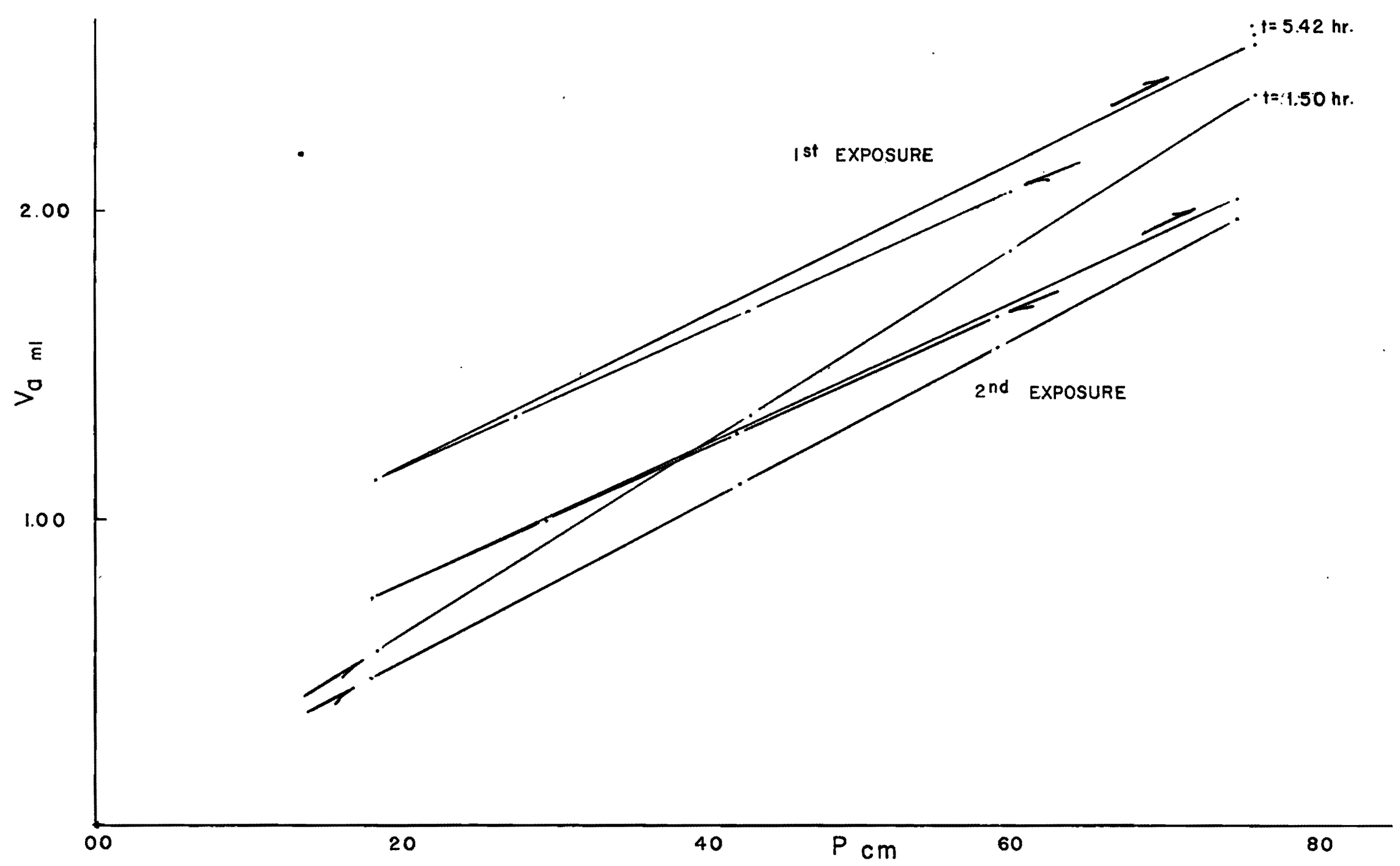

Figure 9. Nitrogen adsorption at $25.0^{\circ}$ on the 28 gram sample of sterilized and stirred Willakenzie soil. 
Experiment 1

A $30 \mathrm{~g}$ sample of nonsterilized Willakenzie soil (Figure 5 and Table IV) was:
a. evacuated for 5 days at room temperature to 2 microns
b. exposed to helium for 3 hours
c. evacuated for 21.5 hours at room temperature to 2 microns
d. exposed to carbon monoxide for 3.8 hours

\section{Experiment 2}

A $28 \mathrm{~g}$ sample of sterilized Willakenzie soil (Figure 8 and Table VI) was:

a. after sterilization, evacuated for 5 days at room temperature to 2 microns

b. exposed to helium for 2 hours

c. evacuated for 24.8 hours at room temperature to 2 microns

d. exposed to carbon monoxide for 2.7 hours

From experiment 1, the volume of carbon monoxide adsorbed was $0.121 \mathrm{cc} / \mathrm{g}$ (first exposure, Table IV). From experiment 2, the volume of carbon monoxide adsorbed was $0.091 \mathrm{cc} / \mathrm{g}$ (first exposure, Table VI): Assuming that the sorptive characteristics of the dead or damaged soil microorganisms present in the sterilized soil contribute only slightly to the total volume of carbon monoxide adsorbed then the difference in the volume of carbon monoxide adsorbed $(0.030 \mathrm{cc} / \mathrm{g})$ between nonsterifized and sterilized soil might be an indication of the effect of the activity of the soil microorganisms present in the nonsterilized soil. However, it seems likely that the soil rather than the microorganisms adsorbs most of the carbon monoxide.

In the above experiments the only significant difference appears to be the exposure time with carbon monoxide. However, hysteresis studies (see below) on nonsterilized and sterilized Willakenzie soil 
demonstrated that by varying the exposure procedure (different or same gases in varying sequence), or varying the exposure or evacuation time, no significant changes in the magnitude of the hysteresis effect was observed.

\section{Hysteresis Studies}

(1) Exposure Procedure - From Figure 4 (50 g sample of nonsterilized Willakenzie Soil)

First Exposure of $\mathrm{CO}$ : Magnitude of hysteresis effect between adsorption and desorption run was $33 \%$ by volume at $18.0 \mathrm{~cm}-\mathrm{Hg}$.

(2) Exposure Procedure - From Figure 5 (30 g sample of nonsterilized Willakenzie Soil)

First Exposure of C0: Magnitude of hysteresis effect between adsorption and desorption run was $32 \%$ by volume at $17.5 \mathrm{~cm}-\mathrm{Hg}$.

(3) Exposure Procedure - From Figure 8 (28 g sample of sterilized Willakenzie Soil)

First Exposure of $\mathrm{CO}$ : Magnitude of hysteresis effect between adsorption and desorption was $22 \%$ by volume at $18.7 \mathrm{~cm}-\mathrm{Hg}$.

Second Exposure of Co: Magnitude of hysteresis effect between adsorption and desorption was $22 \%$ by volume at $16.6 \mathrm{~cm}-\mathrm{Hg}$.

For each of the soil samples studied, $(50 \mathrm{~g}, 30 \mathrm{~g}$, and $28 \mathrm{~g}$ samples) different exposure and evacuation times were used.

These studies would suggest that the difference in exposure time for carbon monoxide in experiments 1 and 2 is not significant.

In addition tonitrogen and carbon monoxide runs, adsorption studies were also carried out with oxygen on sterilized Willakenzie soil. Oxygen was exposed to 28 grams of sterilized Willakenzie soil for 70 hours. The results of the first 3 hours are shown in Figure 10 . The volume of total oxygen adsorbed versus exposure time is shown in Figure 11 for the entire 70 hours. The total volume of oxygen adsorbed 


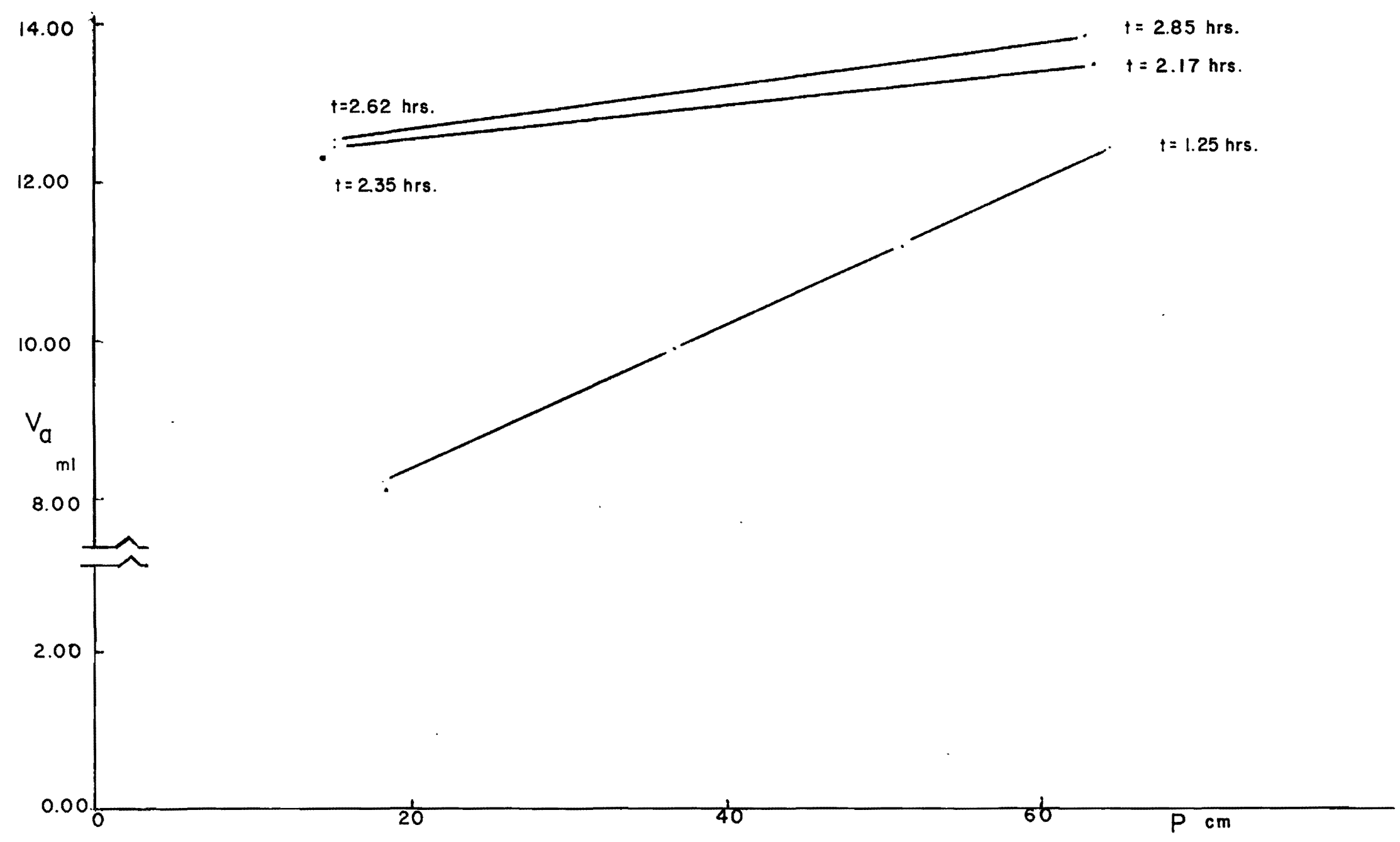

Figure 10. Oxygen adsorption at $25.0^{\circ}$ on the 28 gram sample of sterilized and stirred W11lakenzie soil. 


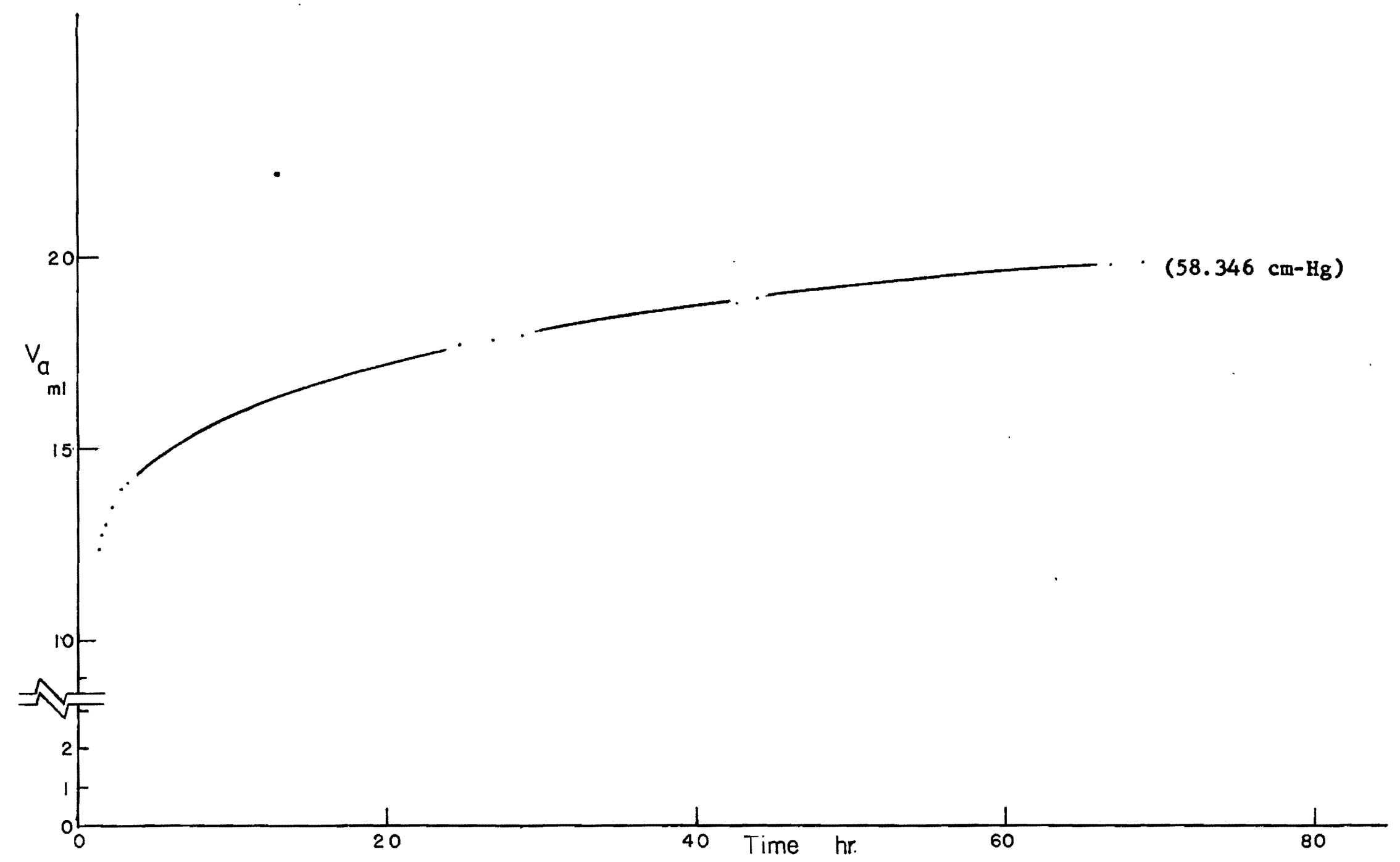

Figure 11. Rate of adsorption at $25.0^{\circ}$ for the 70 hours of oxygen exposure on the 28 gram sample of sterilized and stirred Willakenzie soil. (Pressure range: 51 to $64 \mathrm{~cm}-\mathrm{Hg}$ ) 
at a pressure of $58.346 \mathrm{~cm}-\mathrm{Hg}$ was $19.74 \mathrm{ml}$ at STP. The volume of oxygen that was physically adsorbed was $1.63 \mathrm{ml}$ at STP and the volume chemically adsorbed was $18.11 \mathrm{ml}$ at STP. The $18.11 \mathrm{ml}$ of oxygen chemically adsorbed corresponds to a weight increase of $23.7 \mathrm{mg}$. In this experiment the adsorption vesse1 containing the soil was also weighed before and after oxygen exposure. The weight increase which corresponds to chemically adsorbed oxygen was found to be $23.7 \mathrm{mg}$. This is in excellent agreement to the previously given value found from the volume of oxygen adsorbed.

The oxygen adsorption on sterllized Willakenzie soil is due to two different adsorption processes. The first process (also the smallest adsorption effect) is due to physical adsorption. The magnitude of this physical adsorption as judged by the slope of the upper most curve in Figure 10 is comparable to that found for nonsterilized Willakenzie soll (see Table IV). The second process (the largest adsorption effect) is due to either a chemical adsorption or reaction. It is interesting to note that chemical adsorption of nxygen by sterilized soil has not been reported in the 1 iterature.

It is believed that the chemisorption of oxygen by sterilized Willakenzie soil is due to the dead or damaged soil microorganisms. The oxidation of the dead or damaged microorganisms could possibly produce acid sites in the soil.

In an attempt to acquire additional information on the chemical adsorption of oxygen by sterilized Willakenzie soil, the 28 gram sample of Willakenzie soil was exposed to gaseous ammonia. Also, another one gram sample of sterilized Willakenzie soil was exposed to gaseous 
ammonia. This second sample was not pretreated with oxygen and therefore was considered a control sample.

B.E.T. plots of adsorption isotherms for the ammonia adsorption on the two samples of Willakenzie soil are shown in Figures 12 and 13 respectively. The oxygen exposed sterilized soil was exposed to ammonia for 64 hours and its total volume of ammonia adsorbed was $477.9 \mathrm{ml}$ (see Figure 14). Furthermore, it was found that of the total volume of adsorbed ammonia, $338.6 \mathrm{ml}$ was physically adsorbed while $140.0 \mathrm{~m} 1$ was chemically adsorbed. The relative volumes of physically and chemically adsorbed ammonia were determined in the following manner:

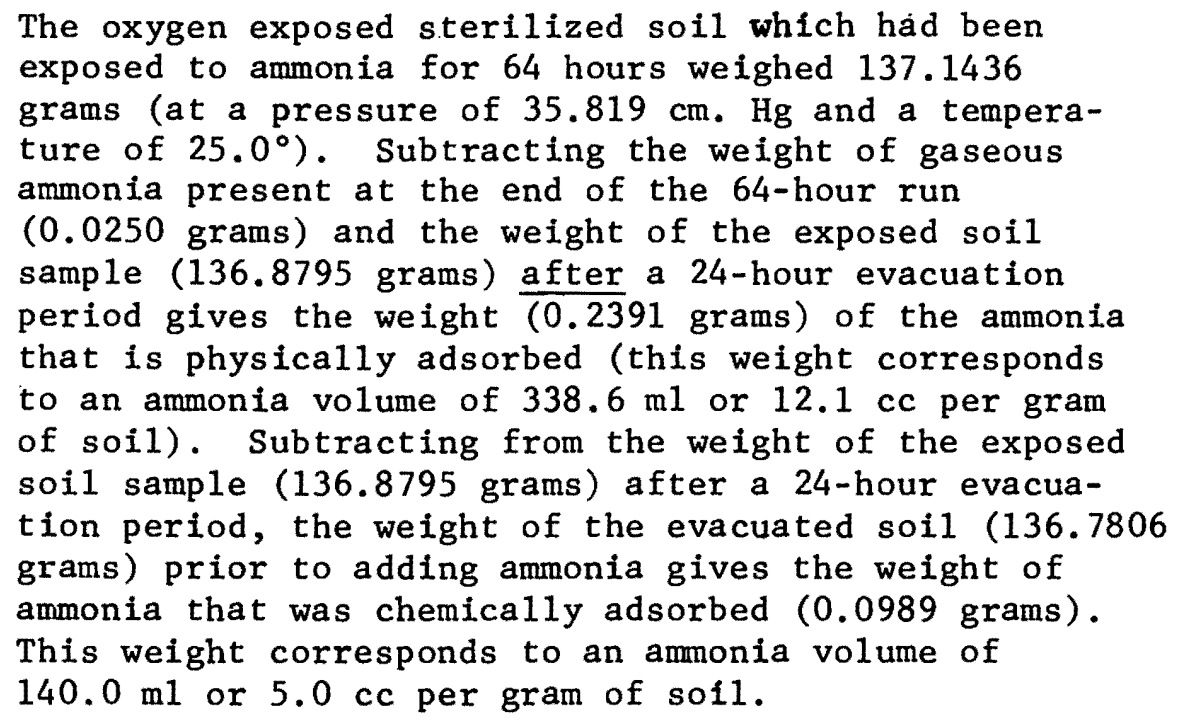

The total volume of ammonia adsorbed as calculated from the weight increase was $478.6 \mathrm{ml} \mathrm{STP}$. This value is within $0.7 \mathrm{~m} 1 \mathrm{STP}$ (1.5 PPT) of the value arrived at from the ammonia adsorption $(477.9 \mathrm{ml} \mathrm{STP})$ as reported in Figure 14.

The one gram control sample that was not exposed to oxygen was exposed to ammonia for 50 hours. The amount of chemically adsorbed 


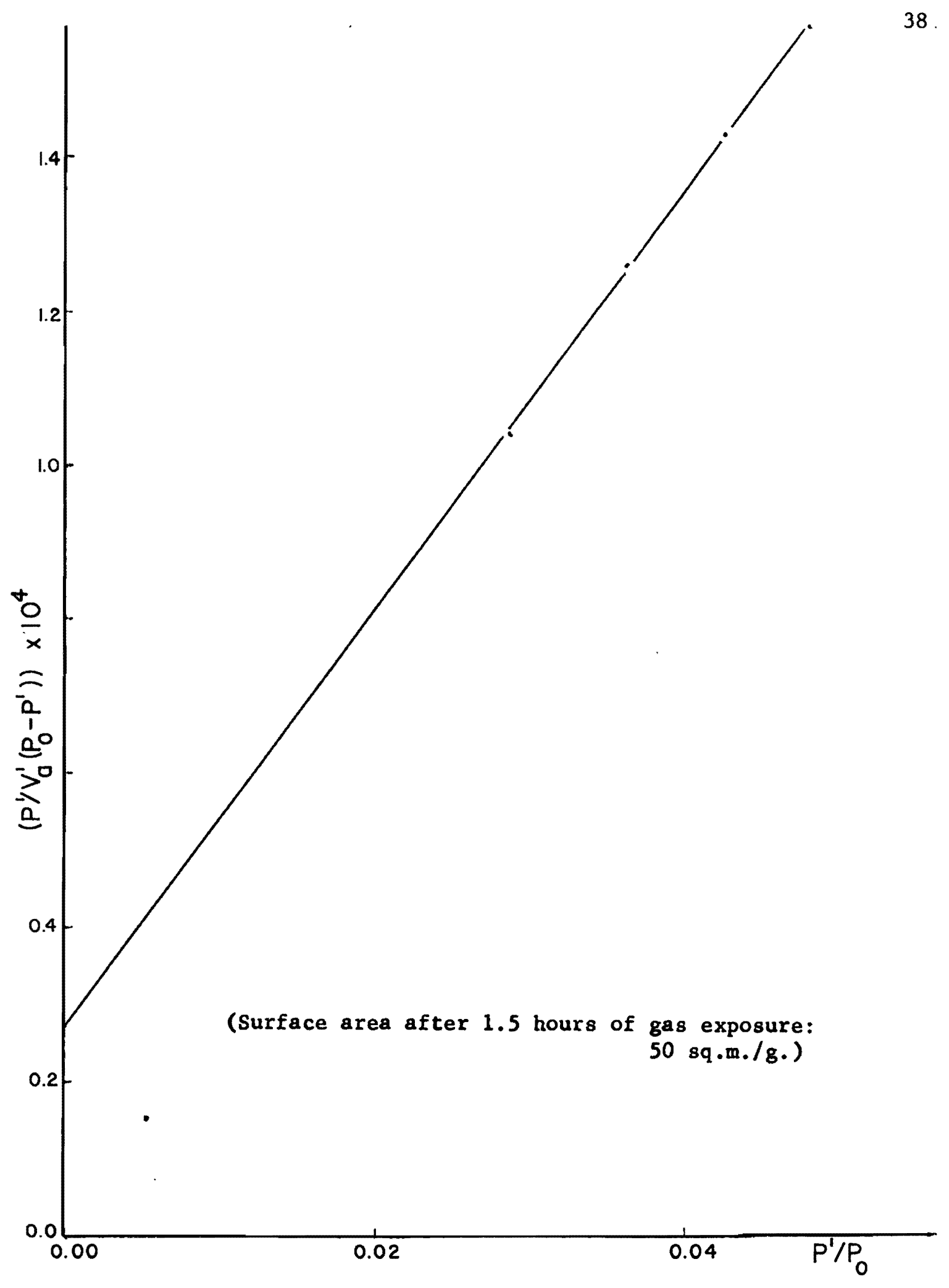

Figure 12. B.E.T. adsorption isotherm for ammonia at $25.0^{\circ}$ on the 28 gram sample of oxygen exposed sterilized and stirred Willakenzie soll. 


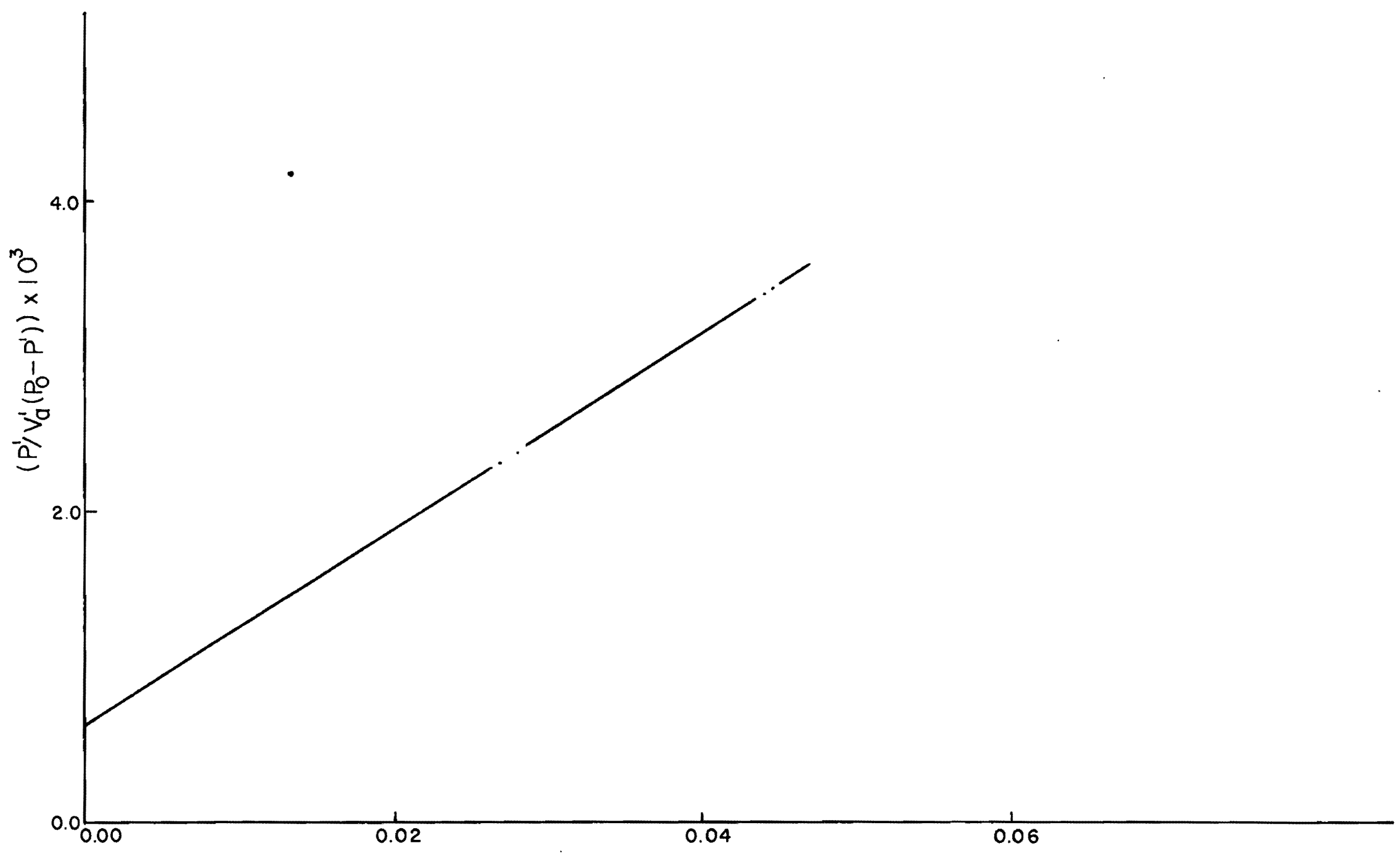

Figure 13. B.E.T. adsorption isotherm for ammonia at $25.0^{\circ}$ on a 1 gram sample of sterilized and nonstirred Willakenzie soil that had not been exposed to oxygen. (Surface area: $58.8 \mathrm{sq} . \mathrm{m} . / \mathrm{g}$.)

$\omega_{\omega}$ 


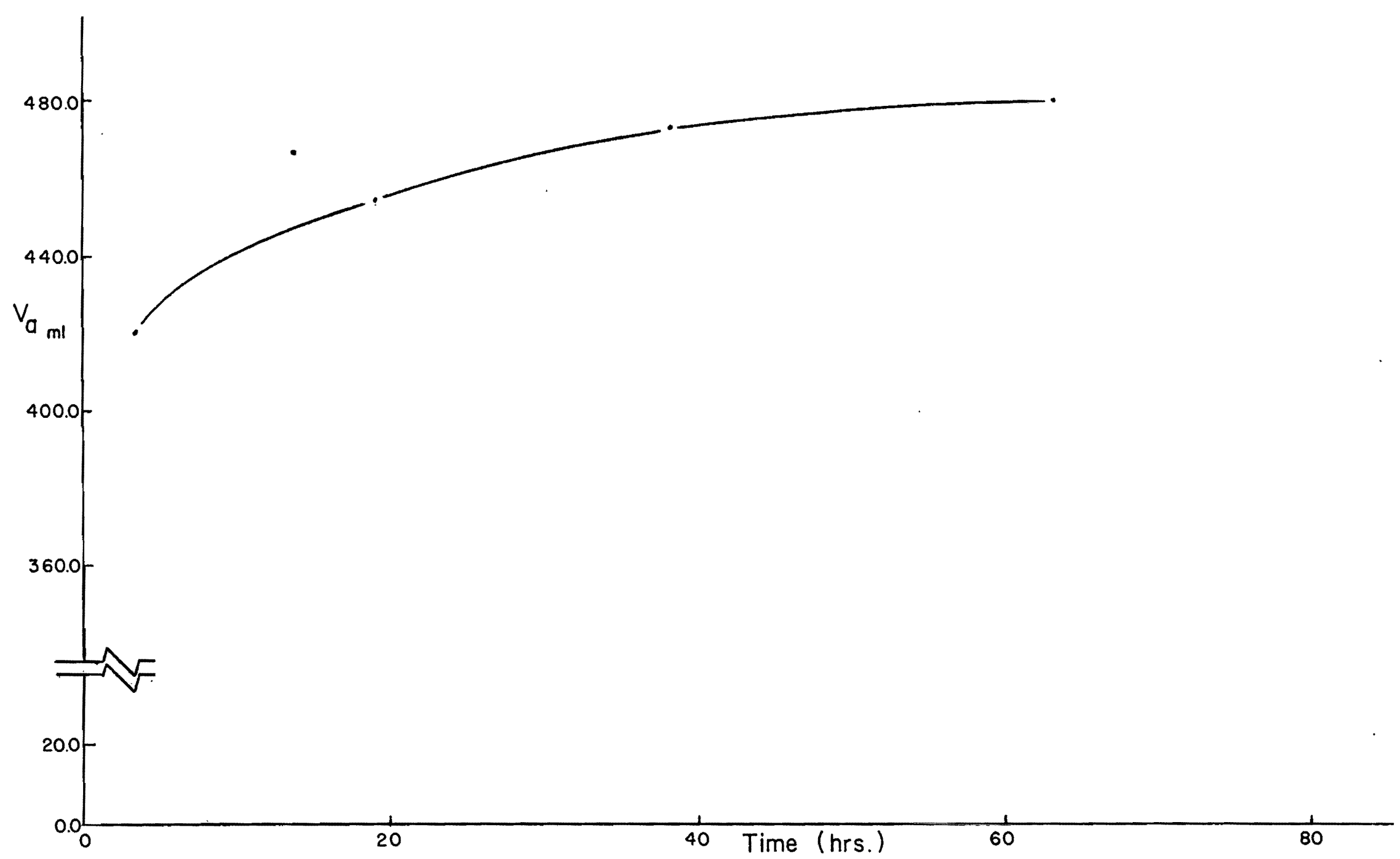

Figure 14. Rate of adsorption at $25.0^{\circ}$ on the 64 hours of ammonia exposure on the 28 gram sample of oxygen exposed sterilized and stirred Willakenzie soil. 
ammonia corresponds to 2.2. cc per gram and was determined in the following manner:

\begin{abstract}
After a 50-hour exposure the one gram sample was evacuated for one hour. The weight of the evacuated sample was 35.6006 grams while the weight prior to the amonia exposure was 35.5990 grams. The difference in weight was 0.0016 gram and represents that weight of chemically adsorbed ammonia. This corresponds to $2.2 \mathrm{cc}$ of ammonia per gram of soil.
\end{abstract}

It was also found that the amount of chemically adsorbed ammonia was essentially the same for a 2 hour or 50 hour exposure time.

Therefore, the results of these runs strongly suggest that the oxygen exposed sterilized soil sample will chemically adsorb about twice as much ammonia as the sterilized soil sample that was not exposed to oxygen. This result would also support the idea that the addition of oxygen produced additional sites (possibly acid groups) in the soil that will chemically bind ammonia molecules.*

\title{
Further Hysteresis Studies
}

For the adsorption runs of carbon monoxide, nitrogen, and oxygen on sterlized and nonsterilized soils at $25.0^{\circ}$ an unexplained hysteresis effect has been present. It was of interest to see if the hysteresis effect was present with argon. Argon was exposed to the $28 \mathrm{gram}$ sterilized Willakenzie soil sample that was previously treated with oxygen and ammonia. Each pressure reading on the adsorption and desorption curves (see Figure 15) was recorded after a $15 \mathrm{~min}$. and $30 \mathrm{~min}$. interval. The 1 ast pressure reading $(17.204 \mathrm{~cm}-\mathrm{Hg})$ of the

\footnotetext{
* From the carbon monoxide runs on Willakenzie soils, it was shown that stirring does not have a significant effect on the volume of gas being adsorbed.
} 


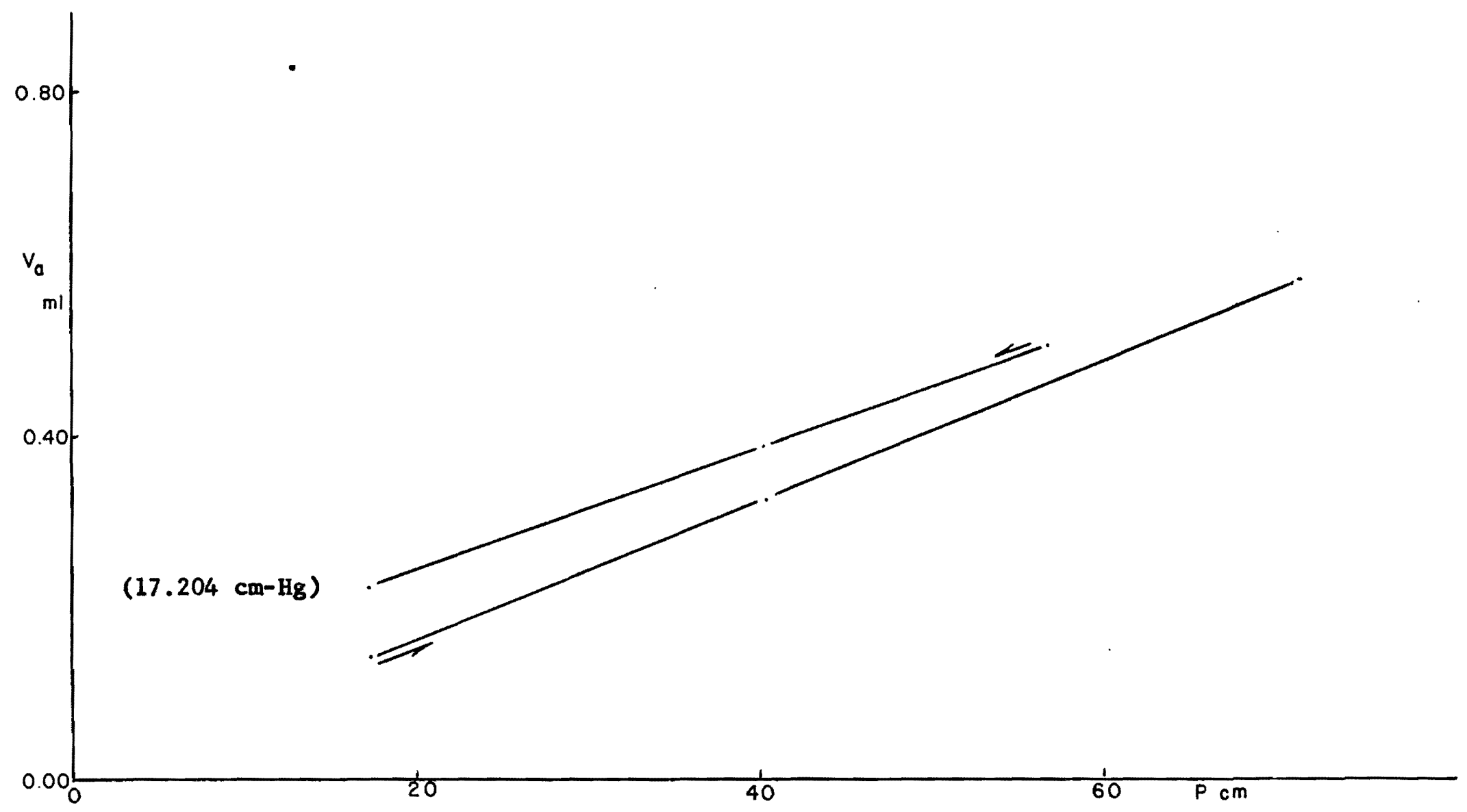

Figure 15. Argon adsorption at 25.0 on the 28 gram sample of oxygen and ammonia exposed sterilized and stirred Willakenzie soil. 
desorption curve was recorded for a 4-hour interval, during which the pressure did not change. As shown in this figure the hysteresis effect is operative even with argon (not previously recorded in literature). Since there were no significant pressure changes during a fourhour interval the hysteresis effect could not be due to a slow diffusion process in the sterilized soil such as a pore-size soil effect or a solubility of the gas in any of the constituents of the sterilized soil.

It should be noted that after the above argon run on the 28 gram sample of oxygen and ammonia exposed sterilized Willakenzie soil was performed, the average volume of helium required to fill the empty space to a unit pressure had increased by about $1 \%$ as compared to $\mathrm{V}_{\mathrm{He}}$ after sterilization and before any gas exposure. This increase in unoccupied space could be due to the lengthy evacuation times which might remove residual water vapor or oxidized organic matter. In order to determine whether the hysteresis effect was due to either the equipment or the soil the following adsorption runs were carried out. Two, three gram samples of silica gel were placed in $a \mathrm{cc}$ and $95 \mathrm{cc}$ sample bulb. The silica gel samples were sterilized in essentially the same manner as reported earlier for the Willakenzie soil.

The 5cc sterilized silica gel sample was exposed to nitrogen and the results are shown in Figure 16. The $95 \mathrm{cc}$ sterilized silica gel sample was exposed to argon and the results are shown in Figure 17. With both silica gel samples no hysteresis effect was found. 


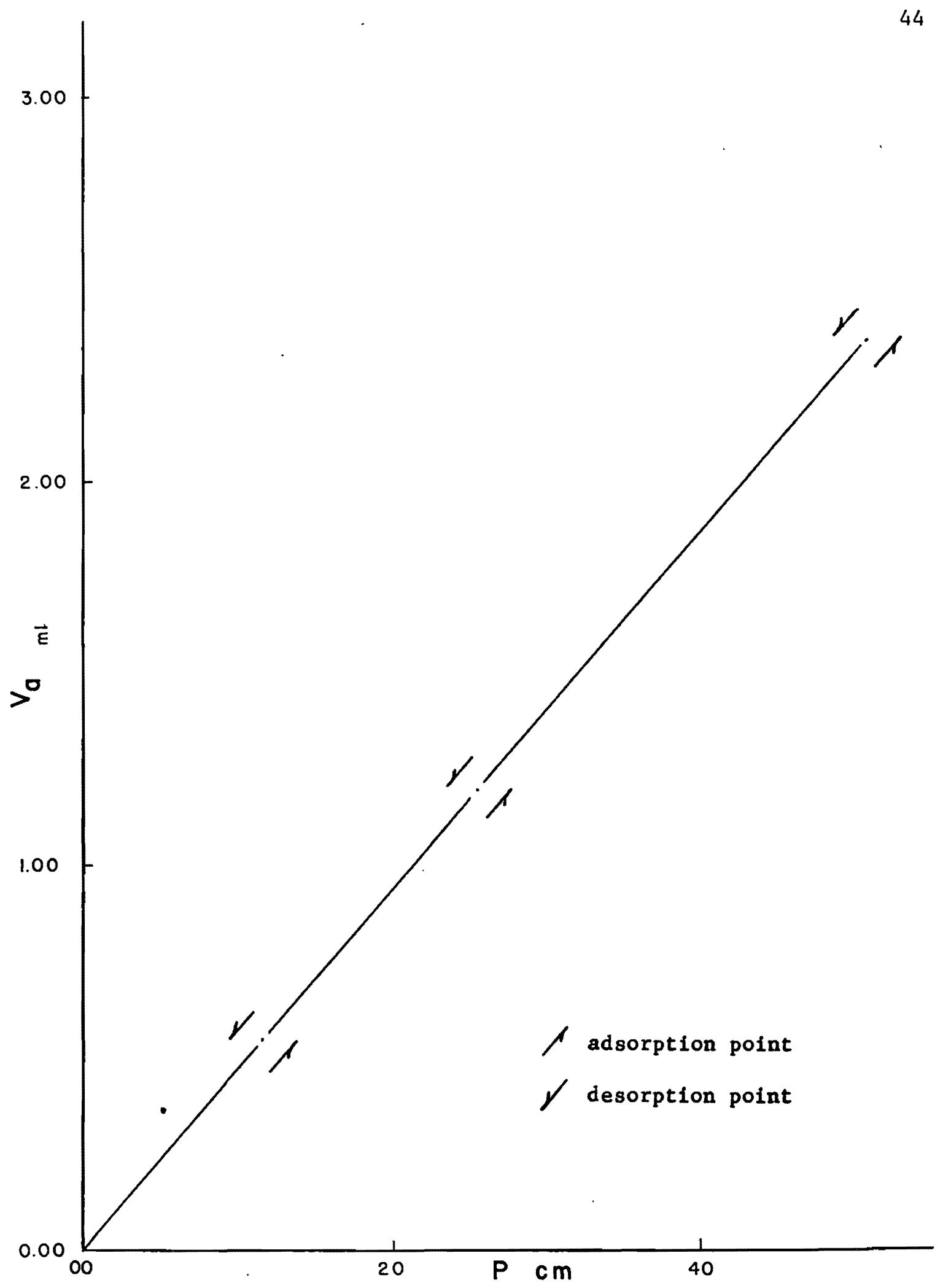

Figure 16. Nitrogen adsorption at $25.0^{\circ}$ on a 3 gram sample of silica gel in a 5 cc. sample bulb. 


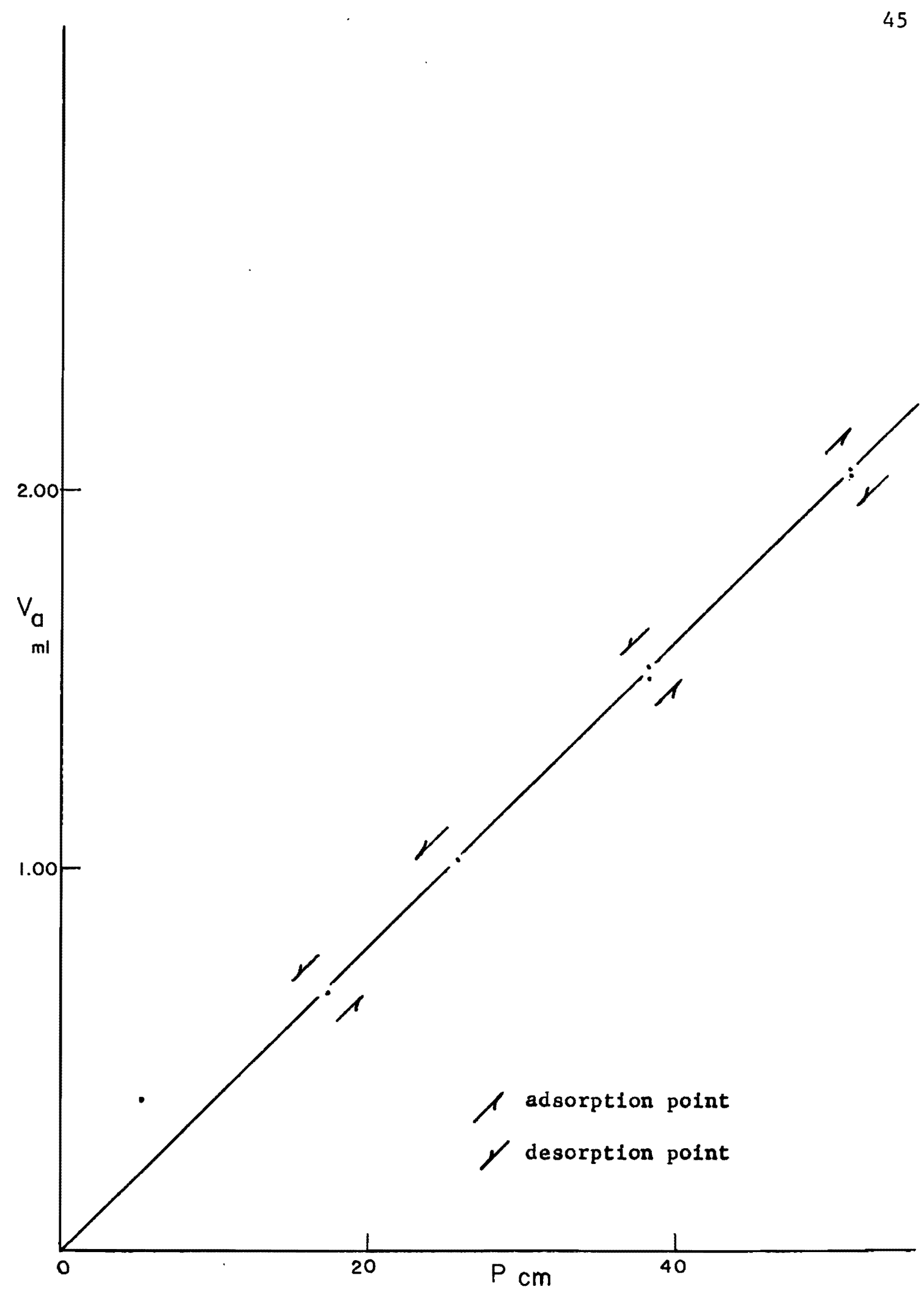

Figure 17. Argon adsorption at $25.0^{\circ}$ on a 3 gram sample of silica gel in a $95 \mathrm{cc}$. sample bulb. 
In order to determine if the hysteresis effect was caused by living microorganisms that might have survived the sterilization procedure, a portion of the 28 gram sample of sterilized Willakenzie soil that had been exposed to oxygen and ammonia was tested along with a sample of nonsterilized Willakenzie soil. The nonsterilized Willakenzie soil showed signs of growth within 24 hours at room temperature whereas the sterilized sample showed no visible growth even after 6 days at room temperature. Therefore, the hysteresis effect appears to be characteristic of the constituents of the soil sample and represents a new and as yet unexplained phenomenon.

\section{Summary}

Adsorption studies of carbon monoxide do not show any adsorption effects on soils in excess of the amount that would be expected as a physical adsorption. Carbon monoxide, nitrogen, and oxygen show physical adsorptions equivalent to the coverage of a few per cent of the surface area of the various soils at $25.0^{\circ}$, which is in agreement with prior observations that have been made for nitrogen and oxygen on various soils $(17,18)$.

Adsorption studies for carbon monoxide also show that the soil rather then the microorganisms adsorbs most of the carbon monoxide. Adsorption sţudies of oxygen on sterilized soil indicates the presence of a chemisorption process which could be the result of the oxidation of dead or damaged soil microorganisms.

In all of the adsorption studies at $25.0^{\circ}$ on the sterilized and nonsterilized soils, the presence of a hysteresis effect was observed between the adsorption and desorption modes of the same gas run. The 
hysteresis effect was not due to any observable experimental error. Therefore, the hysteresis effect appears to be characteristic of the constituents of the soil sample and represents a new and as yet unexplained phenomenon. 


\section{BIBLIOGRAPHY}

1. Ephraim, F. Inorganic Chemistry by Thorne, P.C.L. and Roberts, E.R., 5 th Ed. Rev. Interscience Publishers Inc., 1948, pp 795-814.

2. Robbins, R.C., Borg, K.M., and Robinson, E. Journal of the Air Pollution Control Association, 18 (1968) 106.

3. Jaffe, L.S., ibid., 18 (1968) 534.

4. Weinstock, B. "CO: Residence Time in the Atmosphere." Science, 166 (1969) 224.

5. Waksman, S.A. Principles of Soil Microbiology, Baltimore: William and Wilkens, 1929, p. 98.

6. Inman, R.E., Ingerso11, R.B., and Levy, E.A. "Soil: A Natural Sink for Carbon Monoxide," Science, 172 (1971) 1229.

7. Lineweaver, H. "The Solubility and Chemical and Physical Absorption of Nitrogen Gas in Azotobacter Cel1s." The Journal of Biological Chemistry, 122 (1938) 549.

8. Brunauer, S., Emmett, P.H., and Teller, E. "Adsorption of Gases in Multimolecular Layers." The Journal of American Chemical Society, 60 (1938) 309.

9. Constabaris, G. A High Precision Adsorption Apparatus. Michigan: University Microfilms, 1957.

10. Emmett, P.H. "A New Method for Measuring the Surface Area of Finely Divided Materials and for Determining the Size of Particles." Proceedings of the American Society for Testing Materials, 41 (1941) 95.

11. Powe1l, R.L., Bunch, M.D., and Corruccini, R.J. "Low Temperature Thermocouples - I. Gold-Cobalt or Constantan versus Copper or 'Normal' Silverm." Cryogenics, 1 (March 1961).

12. Private communication with Kauffman, M.D., Soil Testing Laboratory, Oregon State University, Corvallis, Oregon, 97331.

13. Oregon State Water Resources Board, "General Soil Map Report with Irregable Areas: Willamette Drainage Basin." Oregon's LongRange Requirements for Water, App. I-2, 1969. 
14. U.S. Department of Agriculture, Soil Conservation Service in cooperation with the Oregon Agricultural Experiment Station, Soil Survey of the Marion County Area, Oregon, September, 1972.

15. Soil analyzed by Beller Mikroanalytisches Laboratorium, 34 Gottingen Theaterstasse 23, West Germany.

16. U.S. Department of Agriculture, Soil Conservation Service in cooperation with the Oregon Agricultural Experiment station, "Soil Survey of the Yamhil1 County Area, Oregon," to be published.

17. Emmett, P.H., Brunauer, S., and Love, K.S., "The Measurement of Surface Areas of Soils and Soil Colloids by the Use of Low Temperature van der Waals Adsorption Isotherms." Soil Science, 45 (1938) 57.

18. Makower, B., Shaw, T.M., and Alexander, L.T. "The Specific Surface and Density of Some Soils and Their Colloids." Soil Science Society Proceedings, 1937, pp 101-108.

19. Huang, Y. and Emmett, P. "The Effect of Exchanged Cations and Heat Treatment on the Adsorption of Carbon Monoxide, Nitrogen, Argon, and Krypton on Amorphous Silica-Alumina Cracking Catalysts." Journal of Catalysis, 30 (1973) 467.

20. Brunauer, S. and Emmett, P.H. "The Use of van der Waals Adsorption Isotherms in Determining the Surface Area of Iron Synthetic Ammonia Catalysts." Journal of the American Chemical Society, 57 (1935) 1754.

21. Emmett, P.H. and Brunauer, S., "The Use of Adsorption Isotherms for Measuring the Surface Areas of Catalysts and Other Finely Divided Materials." Trans. Electrochemical Society, 71 (1937) 383.

22. Loisch, H.G. "Biocontamination Control." Space/Aeronautics, November, 1966, pp 82-91. 